ANTONIO FERNANDO RIBEIRO JUNIOR

\title{
Análise de Células Satélite em Diferentes Modelos Murinos para Distrofias Musculares
}

Satellite Cells Analysis in Different Murine Models for Muscular Dystrophies

São Paulo 


\title{
Análise de Células Satélite em Diferentes Modelos Murinos para Distrofias Musculares
}

\author{
Satellite Cells Analysis in Different Murine \\ Models for Muscular Dystrophies
}

Dissertação apresentada ao Instituto de Biociências da Universidade de São Paulo, para a obtenção do Título de Mestre em Ciências, na Área de Genética.

Orientadora: Dra. Mariz Vainzof.

São Paulo 


\section{Ficha Catalográfica}

Ribeiro Junior, Antonio Fernando

Análise de Células Satélite em

Diferentes Modelos Animais para

Distrofias Musculares

$65 \mathrm{p}$.

Dissertação (Mestrado) - Instituto

de Biociências da Universidade de São

Paulo. Departamento de Genética e

Biologia Evolutiva.

1. Células Satélite 2. Distrofias

Musculares 3. Células Tronco Musculares

I. Universidade de São Paulo. Instituto de

Biociências. Departamento de Genética e

Biologia Evolutiva

\section{Comissão Julgadora:}

Prof(a). Dr(a).

Prof(a). $\operatorname{Dr}(a)$. Dr(a). Mariz Vainzof

Orientador(a)
Prof(a). Dr(a).

$\operatorname{Prof}(a) . \operatorname{Dr}(a)$. 


\section{Dedicatória}

Aos meus pais, minhas irmãs, meus sobrinhos e minha amada

esposa. 


\section{Epígrafe}

"However bad life may seem, there is always something you can do, and succeed at. While there's life, there is hope." 


\section{Agradecimentos}

À minha querida mãe, que sempre me apoiou em todas minhas decisões, que sempre esteve ao meu lado e que apesar de todas as dificuldades, nunca nos deixou faltar nada. Ao meu pai In memoriam que me ensinou que o trabalho é a ferramenta que molda o homem, que o caráter vale mais que qualquer pedaço de papel e que me criou me mostrando que poderia ser o que quisesse e que tinha orgulho das minhas conquistas. Às minhas irmãs Vi, Cris, Lu, Preta e Josi, que muitas vezes na função de pai e mãe, me deram bronca, me abraçaram, me mostraram o caminho a ser seguido. Passaria o dia descrevendo o que cada uma já fez por mim nesta vida, saibam que todas vocês têm sua parcela de contribuição, cada uma à sua maneira. Não posso mensurar o quanto vocês, minhas irmãs, são importantes na minha vida, o quanto vocês contribuíram e contribuem pra minha felicidade, a vida nos fez fortes e mais unidos. Agradeço a Deus por ter irmãs como vocês e pelos sobrinhos tão maravilhosos que vocês me deram e que amo demais.

À minha segunda família, Dona Vitória, Sr. Henrique, que desde o primeiro momento me acolheram e me trataram como filho. Aos meus cunhados e cunhadas, por sempre me acolherem e tornarem nosso convívio alegre e prazeroso. Todos vocês têm um lugar especial em meu coração! Em especial, agradeço à Ane e ao João que sempre me aconselharam e participaram de perto da minha vida. Também à tia Goreti que sempre se preocupou comigo e cuidou com muito amor do meu bem mais valioso.

Agradeço imensamente à professora Mariz Vainzof pela orientação, ensinamento, apoio profissional e pessoal e pela paciência. Obrigado por compartilhar seu conhecimento, seu tempo, por ter me acolhido neste laboratório e acreditado em $\operatorname{mim}$.

Agradeço a todos do laboratório André, Aurea, Camila, Dani, Léo, Letícia, Lucas, Paula, Renata, Stephanie e Yumi pelo convívio maravilhoso e pela troca de vivências pessoais e profissionais. Aprendi muito com todos vocês estes anos.

Ao André, por todas nossas intermináveis conversas, sobre vida, trabalho, ciência, religião etc. Você se revelou um bom conselheiro e ouvinte. 
À Aurea, apesar de não estar presente durante o mestrado, foi uma pessoa que me ensinou muito, uma verdadeira cientista com uma visão além do normal.

À Camila, por toda ajuda nos experimentos e que apesar de parecer durona, é uma chorona com um coração grande.

À Dani, por toda sua disposição em ajudar e sua paciência. Obrigado por todos os conselhos e volte logo.

À Letícia, que apesar de sua braveza, torna nosso laboratório mais engraçado e mais leve (quando não está brava).

Ao Léo, pela ajuda e pelas conversas e risadas no dia a dia. Apesar de atrapalhado e um "pouco" ansioso, é um excelente cara e tem um belo futuro pela frente. Obrigado também por nos dar nossa Baby Ruth.

Ao Lucas, que trouxe muita alegria consigo, digo com toda certeza que você mudou o astral deste laboratório. Obrigado pela grande ajuda.

À Lydinha, sempre tão atenciosa, me ensinou muito. Pena não termos convivido mais tempo.

Aos colegas Luíz e Ernesto, que com paciência e disponibilidade me ensinaram muito.

À Renata pela amizade, pelos momentos de descontração, pelas muitas cobranças sobre organização e pelos ensinamentos.

À Stephanie, por toda a ajuda durante todo o tempo no laboratório, na produção deste manuscrito e também por todos os conselhos.

À Yumi, pelos momentos de descontração, pelo carinho que trata todos no laboratório e pela ajuda com gráficos e tabelas.

Aos funcionários do Centro de Estudos do Genoma Humano: Wagner, Marta, Daniel, Fernando, Heloísa, Martinha, Neide e tantos outros, por contribuírem direta ou indiretamente para a construção deste projeto. 
Não poderia deixar de agradecer a minha mentora, incentivadora, apoiadora e madrinha Vivian, que desde os primeiros anos de faculdade viu em mim algo diferente, que nem eu mesmo sabia. Obrigado por todo o apoio e por me incentivar a fazer este mestrado e buscar cada vez mais conhecimento, devo muito a você.

Aos amigos Binho, Kei e Mário, pelos momentos de descontração, pelas aulas de culinária, cultura, música etc, e por fazerem este chucro um pouco mais culto. Obrigado por tornarem minha vida em São Paulo mais leve e divertida e por todo o carinho que têm por mim. Em especial agradeço ao Mário, que me questionou, me ouviu e me orientou sobre a vida pessoal e profissional. Obrigado pelo carinho e pela ajuda, você é um destes anjos que Deus coloca em nossas vidas.

Ao meu querido amigo e padrinho Marcos, que apesar da pouca convivência é uma pessoa que contribui para minha vida e que sempre esteve de braços e ouvidos abertos pra mim.

À minha amada esposa Chris, que nestas alturas já deve estar se perguntando, “e eu?". Jamais me esqueceria da pessoa que está ao meu lado todos os dias. Obrigado por toda sua dedicação a mim e ao nosso casamento, pelo seu carinho, pela sua paciência nos momentos mais difíceis, em que nem mesmo eu sabia o que fazer e você estava lá, pra me acalmar. Tenho aprendido, nesses 12 anos, a ser uma pessoa melhor e mais paciente, e você é a razão disso. Hoje conheço um amor imensurável, que jamais imaginei existir no mundo, que foi construído com paciência e dedicação, sobre a rocha. Apesar de todos as pessoas agradecidas aqui me conhecerem, só você me conhece de verdade. Com você, muitas vezes, as palavras são dispensáveis, nossos olhos falam por si. Obrigado por nunca me deixar desistir! Te amo!

Às agências FAPESP, CNPq e Capes pelo financiamento deste projeto. 


\section{Sumário}

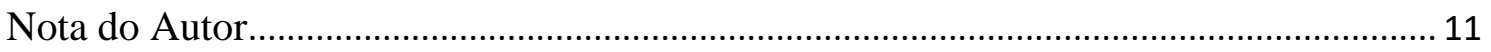

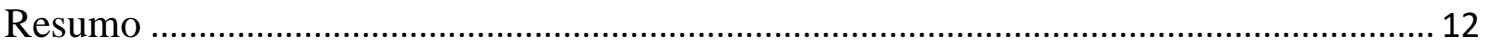

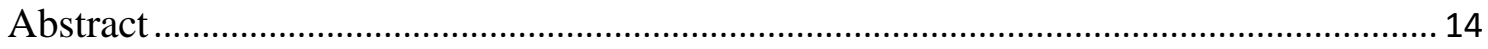

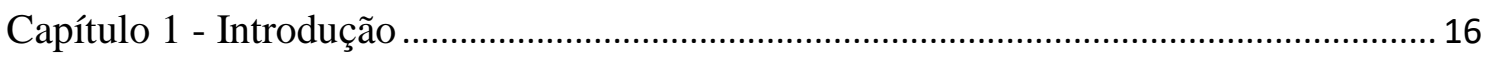

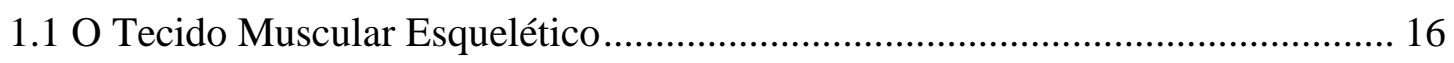

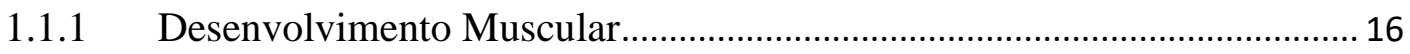

1.1.2 Regeneração Muscular............................................................................ 17

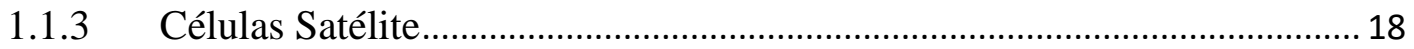

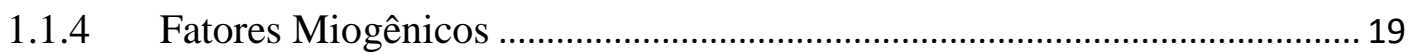

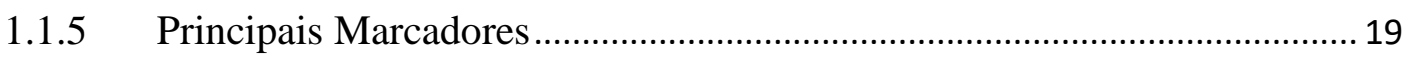

1.1.6 MRFs - Fatores de Regulação Miogênica ................................................... 20

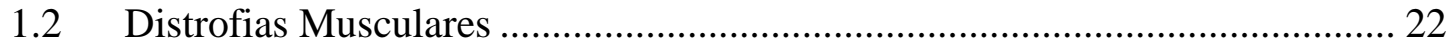

1.2.1 Distrofia Muscular de Duchenne ……...................................................... 24

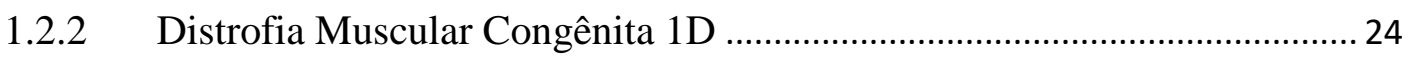

1.3 Células Satélite nas Distrofias Musculares .................................................... 25

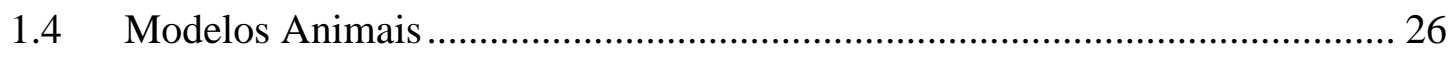

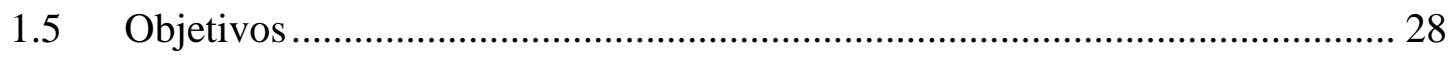

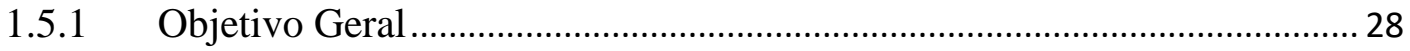

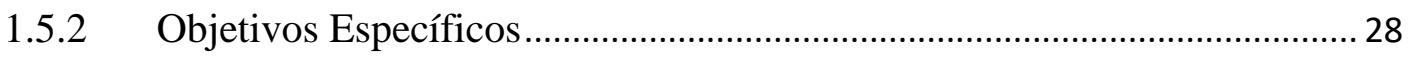

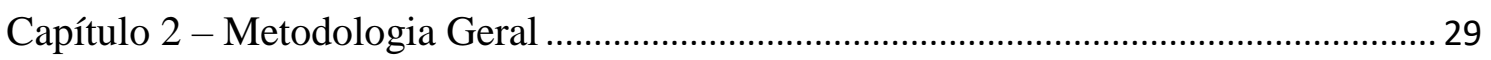

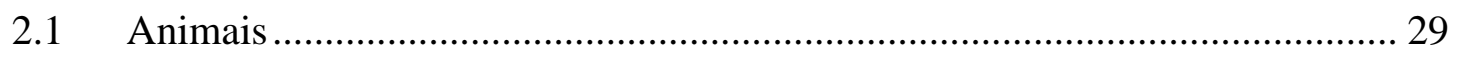

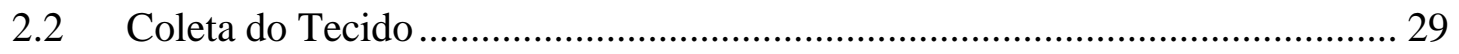

2.3 Estudo de Expressão Gênica (Real-time PCR) ................................................. 29

2.4 Estudo Quantitativo de Proteínas por Western Blot ....................................... 31

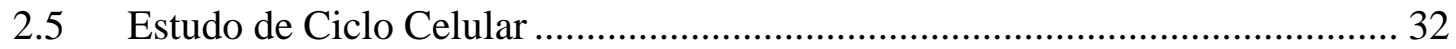

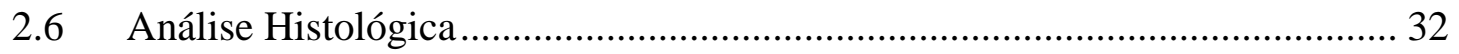

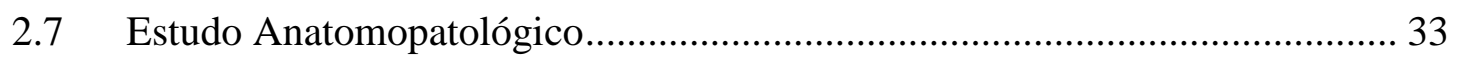

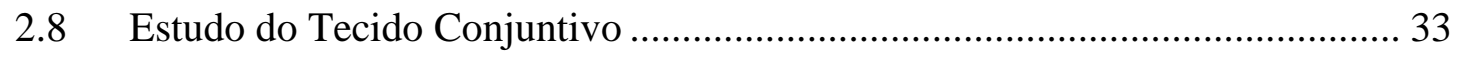

2.9 Análise de Fibras Musculares em Regeneração por Imunofluorescência ....... 34

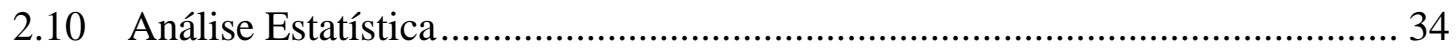


Capítulo 3 - Satellite Cells Analysis in Different Murine Models from Muscular

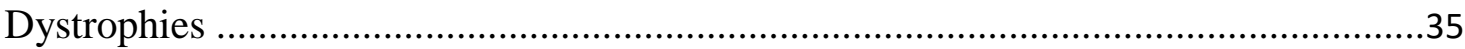

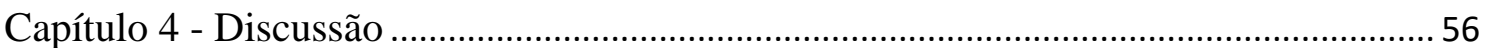


Esta dissertação seguiu o formato de apresentação em capítulos, conforme as diretrizes estabelecidas pelo Instituto de Biociências (IB-USP). No primeiro capítulo é apresentada uma introdução geral, descrevendo aspectos gerais do músculo e da regeneração muscular, bem como informações sobre o comportamento e o papel das células satélite no processo de regeneração do tecido. Ao final do capítulo são expostos os principais objetivos do estudo. O Capítulo 2 traz a metodologia geral compilada. O Capítulo 3 contém um manuscrito de artigo científico, redigido em inglês, que será submetido à publicação em breve. Os demais capítulos foram escritos em português. No Capítulo 4 são apresentadas a discussão geral e as conclusões do trabalho.

As referências bibliográficas do artigo estão listadas no respectivo capítulo. Já as referências citadas na introdução geral, metodologia geral, discussão geral e conclusões estão relacionadas ao final da dissertação. Todas as referências foram redigidas seguindo as normas da $\mathrm{ABNT}$. 


\section{Resumo}

\section{RIBEIRO JUNIOR, Antonio Fernando. Análise de Células Satélite em Diferentes}

Modelos Animais para Distrofias Musculares. 2018. 65f. Dissertação de Mestrado

(Genética) - Instituto de Biociências, Universidade de São Paulo, São Paulo, 2018.

O tecido muscular tem uma alta capacidade de regeneração após lesão, que está diretamente ligada à presença de células satélite (SCs). Essas células são as principais células-tronco do músculo e também têm um papel fundamental no desenvolvimento muscular na embriogênese. Embora quiescentes nos músculos adultos normais, as SCs podem ser ativadas por sinais específicos após lesão muscular. Em doenças caracterizadas por processo de degeneração crônica, como distrofias musculares, as SCs são constantemente ativadas, e esta condição pode levar à depleção do pool de SCs e consequente falha no processo regenerativo. Nós estudamos as SCs musculares nas linhagens distróficas murinas $D M D^{m d x}$, Large $e^{m y d}, D M D^{m d x} / \operatorname{Larg} e^{m y d}$, em comparação a camundongos normais, com o principal objetivo de avaliar o comportamento das SCs em músculos distróficos com diferentes graus de degeneração histopatológica. A expressão de genes e proteínas de fatores de transcrição relacionados a SCs foram estudadas no músculo, e os resultados foram comparados com as características histopatológicas de regeneração e degeneração e estado de proliferação de células musculares. Nossos resultados mostraram que o músculo distrófico mantém seu pool de células satélite, expressando PAX7, um importante fator muscular para autorrenovação do pool de SCs, em níveis semelhantes em todas as linhagens distróficas e controle normal. As células isoladas de músculo distrófico apresentaram uma maior proporção de células em proliferação, como observado pela análise dos marcadores de ciclo celular no músculo gastrocnêmio dissociado, com maior número de células na fase G2/M. A cascata de genes de regeneração é ativada no músculo distrófico, com altos níveis de expressão de fatores de regeneração muscular, como MYOD e Myogenin. O músculo distrófico mantém a capacidade de formar novas fibras, observado por um número significativo de fibras recém-formadas, que expressam dMHC, em todas as linhagens analisadas. No entanto, essas novas fibras mostram características de maturação incompleta, como tamanho pequeno e pouca variação em seu calibre, que pode ser determinante para sua disfunção. A degeneração muscular é intensa apesar da regeneração, com infiltração significativa de tecido conjuntivo em camundongos 
distróficos. Em conclusão, nossos achados sugerem que os músculos distróficos, independentemente do grau de degeneração, mantêm o pool de células satélite com capacidade proliferativa e estão prontos para responder aos estímulos regenerativos. Por outro lado, a maturação dessas novas fibras é incompleta e não previne a degeneração do músculo.

Palavras-chave: Células satélite; Distrofia Muscular; Células-tronco musculares; Regeneração muscular. 


\begin{abstract}
RIBEIRO JUNIOR, Antonio Fernando. Satellite Cells Analysis in Different Murine Models for Muscular Dystrophies. 2018. 65f. M.S. Dissertation (Genetics) - Instituto de Biociências, Universidade de São Paulo, São Paulo, 2018.
\end{abstract}

Muscle tissue has a high regeneration capacity after injury, which is directly linked to satellite cells (SCs). These cells are the main stem cells of the muscle and also have a key role in muscle development in embryogenesis. Although quiescent in normal adult muscles, SCs can be activated by specific signals upon muscle injury. In diseases characterized by chronic degeneration process, such as muscular dystrophies, the SCs are constantly activated, leading to depletion of the SC pool and consequent failure of the regenerative process. We studied muscle SCs in the mouse dystrophic strains $D M D^{m d x}$, Large $e^{m y d}$, $D M D^{m d x} /$ Large $e^{m y d}$, comparing to wild-type mice, with the main objective to evaluate SCs behavior in dystrophic muscles with different degrees of histopathological degeneration.

Gene and protein expression of transcription factors related to SCs were studied in the muscle, and the results were compared to regenerating and degenerating histopathologic pattern and proliferative state of muscle cells. Our results showed that the dystrophic muscle retains its satellite cells pool, expressing PAX7, an important muscle factor for self-renewal of the SCs pool, at similar levels in all dystrophic strains and wild-type. Dystrophic muscle single cells presented a higher proportion of proliferating cells, as observed by the analysis of cell cycle markers in dissociated gastrocnemius muscle, with a greater number of cells in the G2/M phase. The cascade of regeneration genes is activated in the dystrophic muscle, with high levels of expression of muscle regenerating factors, such as MYOD and Myogenin. Dystrophic muscle retains the ability to form new fibers, as observed by a significant number of new fibers expressing $\mathrm{dMHC}$ in all dystrophic strains. However, these new fibers show incomplete maturation characteristics, such as small size and no variation in fiber caliber, which could be determinant for its dysfunction. Muscle degeneration is intense in spite of regeneration, with significant more connective tissue infiltration in dystrophic mice than wild-type mice. In conclusion, our findings suggest that dystrophic muscles, independently of the degree of degeneration, retain the pool of satellite cells with proliferating capacity and 
ready to respond to regenerating stimuli. On the other hand, the maturation of these new fibers is incomplete and do not prevent the degeneration of the muscle.

Keywords: Satellite cells; Muscular dystrophies; Muscle stem cells; muscle regeneration. 


\section{Capítulo 1 - Introdução}

\subsection{O Tecido Muscular Esquelético}

O músculo esquelético representa cerca de metade da massa corpórea humana e é responsável por praticamente todos os movimentos controlados voluntariamente. $\mathrm{O}$ tecido muscular é composto por feixes de fibras originadas a partir da fusão de células mononucleadas, denominadas mioblastos, formando um sincício. Estas fibras são multinucleadas e seus núcleos estão localizados perifericamente. Cerca de $80 \%$ do sarcoplasma das fibras musculares é preenchido por miofibrilas que, por sua vez, são formadas pelo conjunto de sarcômeros. Os sarcômeros consistem principalmente de filamentos de actina e miosina que conferem as estriações transversais características das unidades contráteis do músculo. O músculo esquelético é envolto por um arcabouço de tecido conjuntivo que envolve cada fibra individualmente e também o músculo como um todo, formando uma macro-unidade contrátil (Gianakopoulos et al., 2011; Shadrach e Wagers, 2011; Kim et al., 2015).

\subsubsection{Desenvolvimento muscular}

Todos os músculos dos vertebrados são originados da mesoderme, sendo a maioria dos músculos esqueléticos, incluindo os músculos do tronco e dos membros, originada a partir de células progenitoras musculares localizadas no dermomiótomo, uma região mais amadurecida dos somitos (Bentzinger et al., 2012). O desenvolvimento muscular passa por diversas fases. Na fase inicial da miogênese embrionária, célulastronco musculares dão origem aos mioblastos embrionários que se diferenciam em miócitos, que por sua vez se fundem para gerar as primeiras fibras musculares que servirão como molde para o desenvolvimento muscular durante a miogênese na fase fetal. Nesta fase, miócitos podem fundir-se as fibras primárias ou fundir entre si a fim de gerar fibras secundárias adicionais. Logo após, ocorre uma rápida proliferação e fusão dos mioblastos neonatais, que são responsáveis por um intenso crescimento muscular e pela maturação observada durante a miogênese neonatal. Durante a fusão dos mioblastos e a formação dos miotubos, os mionúcleos primeiramente localizam-se no centro do miotubo ou da miofibra imatura, e no decorrer da síntese de miofibrilas, o núcleo migra gradualmente para a periferia, adquirindo uma posição subsarcolemal. No músculo esquelético adulto, observamos a citoarquitetura das fibras musculares com 
tamanho similar e fibras com núcleos localizados na sua periferia (Parker et al., 2003; Abmayr e Pavlath, 2012; Bentzinger et al., 2012).

\subsubsection{Regeneração Muscular}

Uma característica do tecido muscular esquelético é sua alta capacidade de regeneração, que segue uma série de passos que recapitulam as fases do desenvolvimento muscular (Bentzinger et al., 2012). No músculo adulto, existe uma subpopulação de células musculares parcialmente indiferenciadas, mononucleares, que se localizam nas periferias dos miotubos maduros e das fibras musculares, entre o sarcolema e a lâmina basal. Estas células são denominadas células satélite (SCs), também chamadas de células precursoras miogênicas (Mauro, 1961), que conferem à musculatura uma grande capacidade de se adaptar a demandas como crescimento e lesão. Quando não estimuladas, as SCs permanecem num estado quiescente e não proliferativo (Chen e Goldhamer, 2003). Esta população de células precursoras musculares pode suportar diversos ciclos de degeneração e regeneração (Charge e Rudnicki, 2004). Na degeneração é possível observar a morte das fibras musculares por apoptose ou necrose. Assim, em decorrência deste processo, é possível observar a ativação de células mononucleadas, especialmente células inflamatórias e SCs, que determinam a indução da regeneração muscular.

Após a ativação, as SCs podem diferenciar-se em um progenitor miogênico e migrar até o local da lesão para atuar na reparação da fibra muscular danificada, fundindo-se a ela (hipertrofia) ou dar origem a novas fibras através da fusão entre si (hiperplasia) (Figura 1) (Hawke e Garry, 2001). Posteriormente, a fibra passará por um processo de maturação (Bischoff e Heintz, 1994; Rudnicki et al., 2008). 


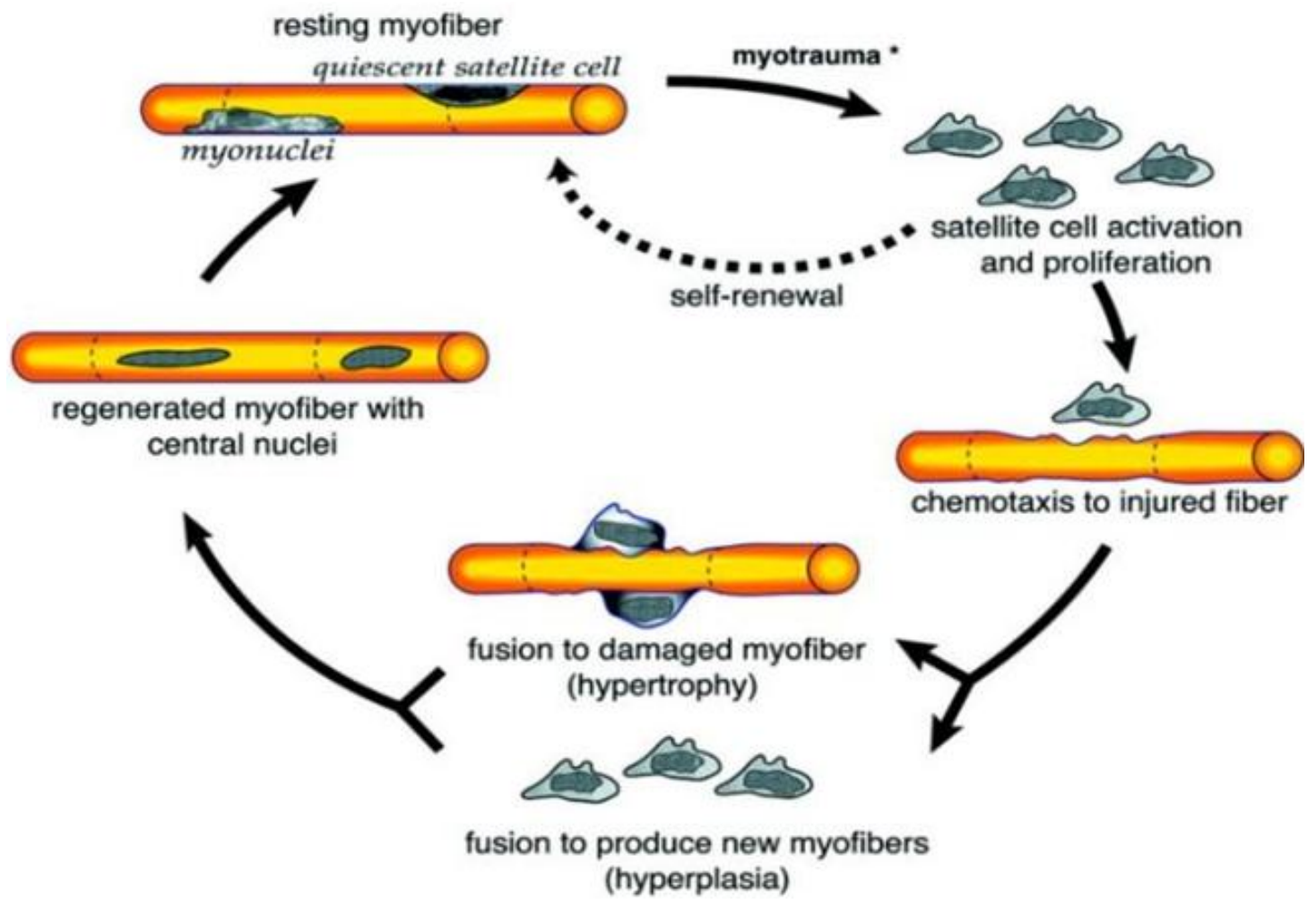

Figura 1: Ação das células satélite na regeneração muscular. Hiperplasia e hipertrofia. Fonte: Hawke e Garry, 2001

\subsubsection{Células Satélite}

As SCs foram identificadas e nomeadas em 1961 a partir de estudos de fibras musculares isoladas de sapo, utilizando microscópio eletrônico (Mauro, 1961).

Anatomicamente, as SCs estão localizadas entre o sarcolema e a lâmina basal da fibra muscular. A proximidade com as fibras auxilia na rápida resposta destas células às lesões e à necessidade de crescimento do músculo. As SCs estão aptas a gerar, tanto progenitores miogênicos, quanto aumentar a reserva de células-tronco existentes no músculo. Isso pode ser alcançado pela divisão assimétrica, onde são gerados um progenitor miogênico e uma célula-tronco, pela divisão simétrica, onde são geradas duas células-tronco idênticas à célula mãe, bem como pela diferenciação direta, onde as SCs não passam por um processo de divisão e se diferenciam diretamente em um progenitor miogênico (Rudnicki et al., 2008; Shadrach e Wagers, 2011). Atualmente, sabe-se que as SCs são responsáveis pelo crescimento muscular, assim como pela reparação do músculo em resposta ao estresse, que pode ser causado por exercício, lesão ou doença. 
Embora inicialmente caracterizada pela localização anatômica, a nossa compreensão de células-tronco musculares expandiu-se consideravelmente com a descoberta de métodos mais sofisticados de isolamento e visualização, assim como sua identificação através da expressão de fatores de transcrição específicos, utilizados como marcadores.

\subsubsection{Fatores Miogênicos}

As SCs podem ser identificadas pela expressão de diversos marcadores (Figura 2), alguns nucleares, como fatores de transcrição, e outros de membrana, como alguns receptores. Em especial, podemos destacar PAX7, que é um fator de transcrição expresso em quase todas as SCs. Alguns marcadores são únicos e outros são expressos em diferentes tipos celulares, por isso é necessária a combinação destes marcadores para a correta identificação.

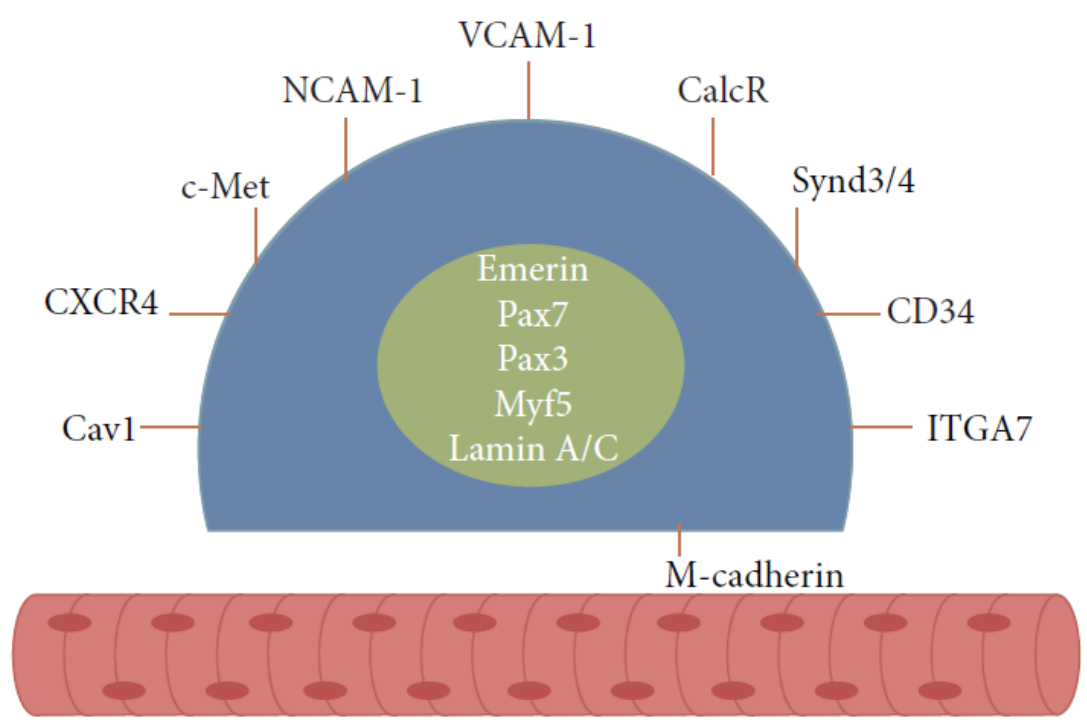

Figura 2: Marcadores utilizados na identificação de SCs. Fonte: Almeida et al., 2016

\subsubsection{Principais marcadores}

Os principais marcadores que permitem a identificação das SCs estão descritos abaixo:

PAX3 - fator de transcrição importante na fase inicial de desenvolvimento muscular e está relacionado à manutenção do pool de SCs durante a miogênese embrionária. 
Durante a fase final do desenvolvimento fetal, na maioria dos músculos, as SCs diminuem a expressão de PAX3 enquanto é mantida a expressão de PAX7.

PAX7 - considerado o principal fator de definição deste tipo celular. Presente no núcleo, este fator de transcrição está associado à manutenção do pool de SCs, sendo um importante fator de autorrenovação. Apesar da expressão de PAX7 ser característica de praticamente todas as SCs, o nível de expressão pode variar a depender do músculo analisado.

M-caderina - proteína de membrana que está envolvida na regulação da morfogênese do músculo esquelético, tanto pré-natal, quanto na regeneração do músculo adulto. Auxilia no reconhecimento célula-célula durante o processo de fusão e é crucial para a ativação da divisão celular.

\subsubsection{MRFs - Fatores de regulação miogênica}

Os fatores de regulação miogênica (MRFs) são fatores de transcrição que atuam exclusivamente em células musculares e são fundamentais para a formação do músculo no embrião e para a regeneração muscular no músculo adulto. Os mais significativos estão descritos abaixo:

MYF5 - marcador de definição da linhagem muscular e pode ser expresso juntamente com PAX7. É o primeiro dos MRFs a ser expresso e exerce papel chave no desenvolvimento e na regeneração muscular.

MYOD - é expresso em níveis extremamente baixos e até não detectáveis em SCs quiescentes. A expressão de MYOD é ativada em resposta a exercícios ou dano muscular. A elevada expressão em SCs reprime a renovação celular e promove a diferenciação.

Miogenina (MYOG) - é expresso em mioblastos em fase final de diferenciação e na fusão dos miócitos para formação de miotubos e, posteriormente, fibras musculares.

MYF6 (ou MFR4) - atua como a miogenina na parte final da diferenciação dos mioblastos.

Apesar da diferença entre os fatores de transcrição e de como eles agem na célula, existe certa sobreposição no período de expressão e/ou atuação. A expressão 
e/ou atuação de um fator de transcrição, muitas vezes, acontece de forma simultânea com a de outro fator, mesmo que tenham papéis diferentes (Figura 3).

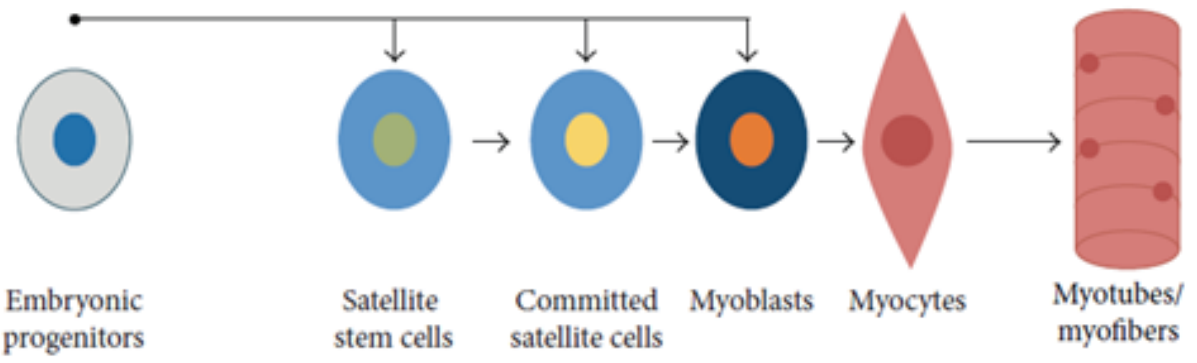

(a)

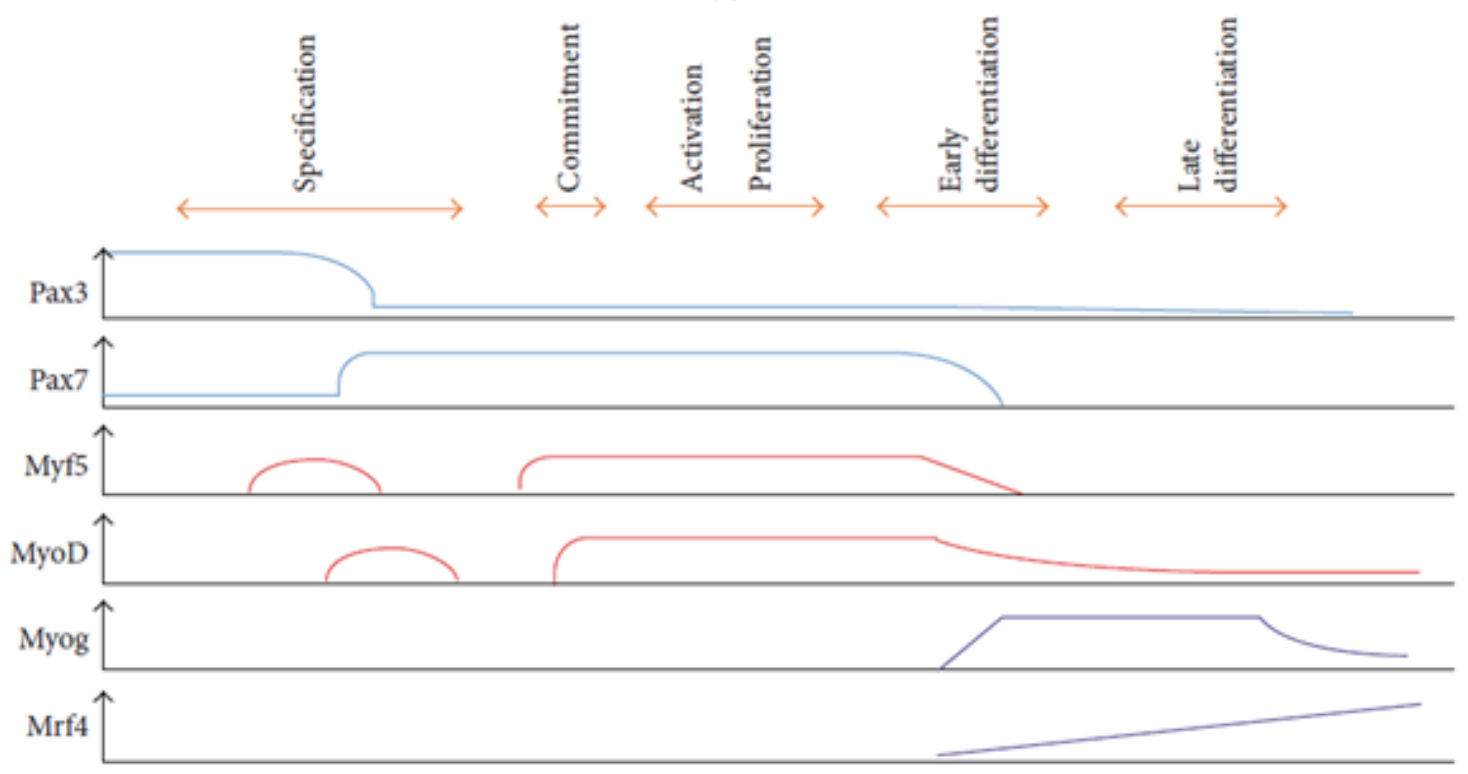

Figura 3: Representação esquemática dos fatores miogênicos envolvidos na ativação, proliferação e diferenciação de células satélite durante a miogênese. Modificado de: Almeida et al., 2016

Até a presente data, não existem patologias associadas à mutações em genes dos fatores de transcrição miogênicos, mas é certo que alterações no padrão de expressão de alguns destes fatores podem influenciar no desenvolvimento dos músculos. Trabalhos realizados em modelos nocaute para estes fatores apresentaram evidências significativas sobre a importância destes fatores de transcrição no desenvolvimento muscular. Em modelos animais nocaute para Pax7 nota-se a ausência de formação de mioblastos por SCs (Seale et al., 2004). Em modelos animais duplo-nocaute para $M y o D / M y f 5$, ocorre morte prematura dos animais devido à não formação de músculo esquelético (Rudnicki et al., 1993). Com a inativação apenas de $M y f 5$, ocorre morte perinatal dos camundongos por incapacidade respiratória, apesar da musculatura esquelética não apresentar alterações morfológicas (Braun et al., 1992). A inativação do gene do fator de transcrição MyoD 
leva ao aumento na expressão de $M y f 5$, que por sua vez, leva à formação aparentemente normal da musculatura esquelética (Rudnicki et al., 1992).

\subsection{Distrofias Musculares}

Distrofias musculares são um grupo de doenças musculares genéticas caracterizadas por perda progressiva e irreversível de células musculares, o que leva à fraqueza e perda de capacidade motora. A fraqueza muscular se evidencia através do desequilíbrio nos ciclos de degeneração e regeneração, que, por falhas nos processos regenerativos, levam à infiltração do músculo por tecido conjuntivo, adiposo e células da resposta inflamatória. A progressão clínica das distrofias musculares apresenta alta variabilidade, ocorrendo desde formas congênitas com progressão rápida e acometimento muscular severo até formas de início tardio e com acometimento muscular brando (Emery, 2002; Vainzof e Zatz, 2003). A grande heterogeneidade se revela nas mais de 40 formas de distrofias musculares com genes já descritos, variando também quanto ao padrão de herança e aos grupos musculares afetados (Mercuri e Muntoni, 2013). Diversos genes e seus produtos proteicos foram e têm sido relacionados com diferentes formas de distrofias. A ausência total, parcial ou a perda de função de proteínas de matriz extracelular, membrana nuclear, citoesqueleto e sarcolemais, leva a um quadro secundário de instabilidade do sarcolema, influxo de cálcio, estresse oxidativo, respostas inflamatórias e desarranjo da matriz extracelular. Todo este processo conduz à instabilidade estrutural do músculo esquelético e à perda progressiva das fibras musculares (Emery, 2002; Shin et al., 2013).

De acordo com o padrão de distribuição de fraqueza predominante, as distrofias musculares podem ser divididas em subgrupos que incluem Duchenne e Becker, EmeryDreifuss, cinturas, fácio-escápulo-umeral, distal e oculofaríngea (Figura 4) (Emery, 1998; 2002). 


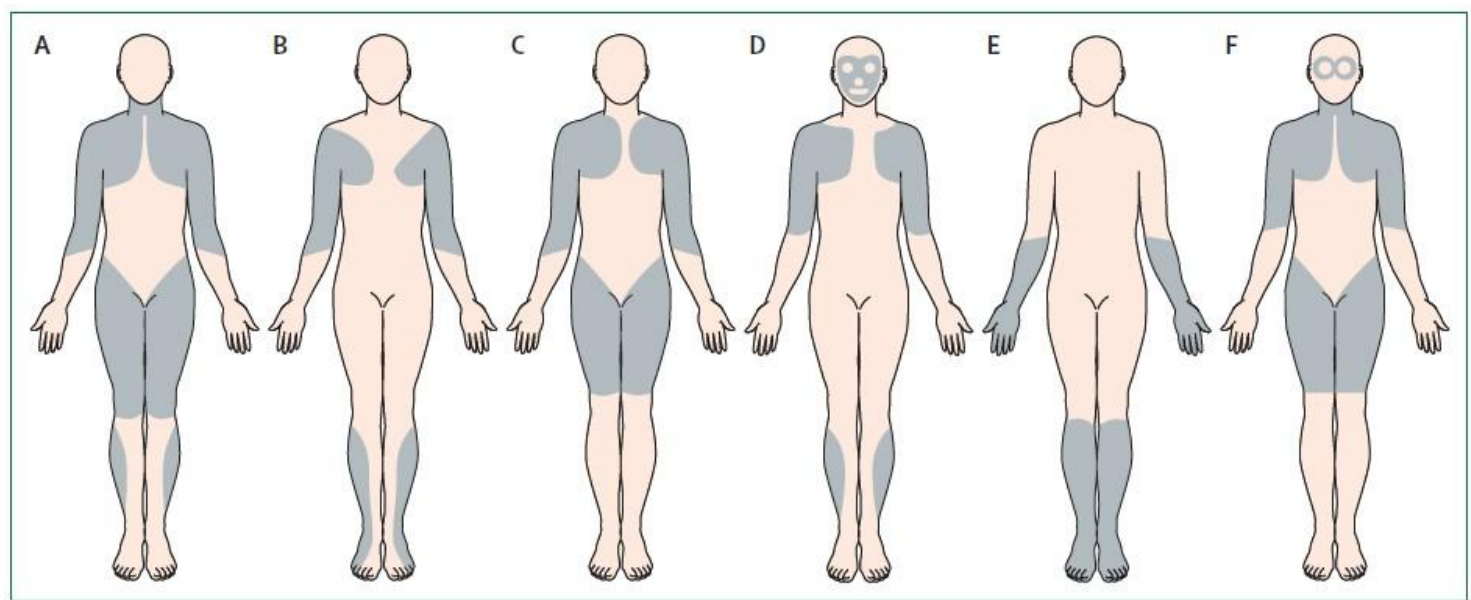

Figura 4: Padrões de distribuição dos músculos mais afetados em diferentes tipos de distrofias musculares. (A) Duchenne e Becker; (B) Emery-Dreifuss; (C) Cinturas; (D) Fácioescápulo-umeral; (E) Distal; (F) Oculofaríngea. Modificado de: Emery, 1998

As distrofias musculares podem ser causadas por defeitos em genes que codificam proteínas relacionadas ao complexo distrofina-glicoproteínas associadas (CDG) (Figura 5). Estas proteínas podem ser estruturais ou associadas ao complexo. Um exemplo de proteína estrutural do complexo é a Distrofina, relacionada à Distrofia Muscular de Duchene (DMD) e Distrofia Muscular de Becker (DMB), enquanto um exemplo de uma proteína associada é a glicosiltransferase LARGE, relacionada à Distrofia Muscular Congênita 1D (DMC1D).

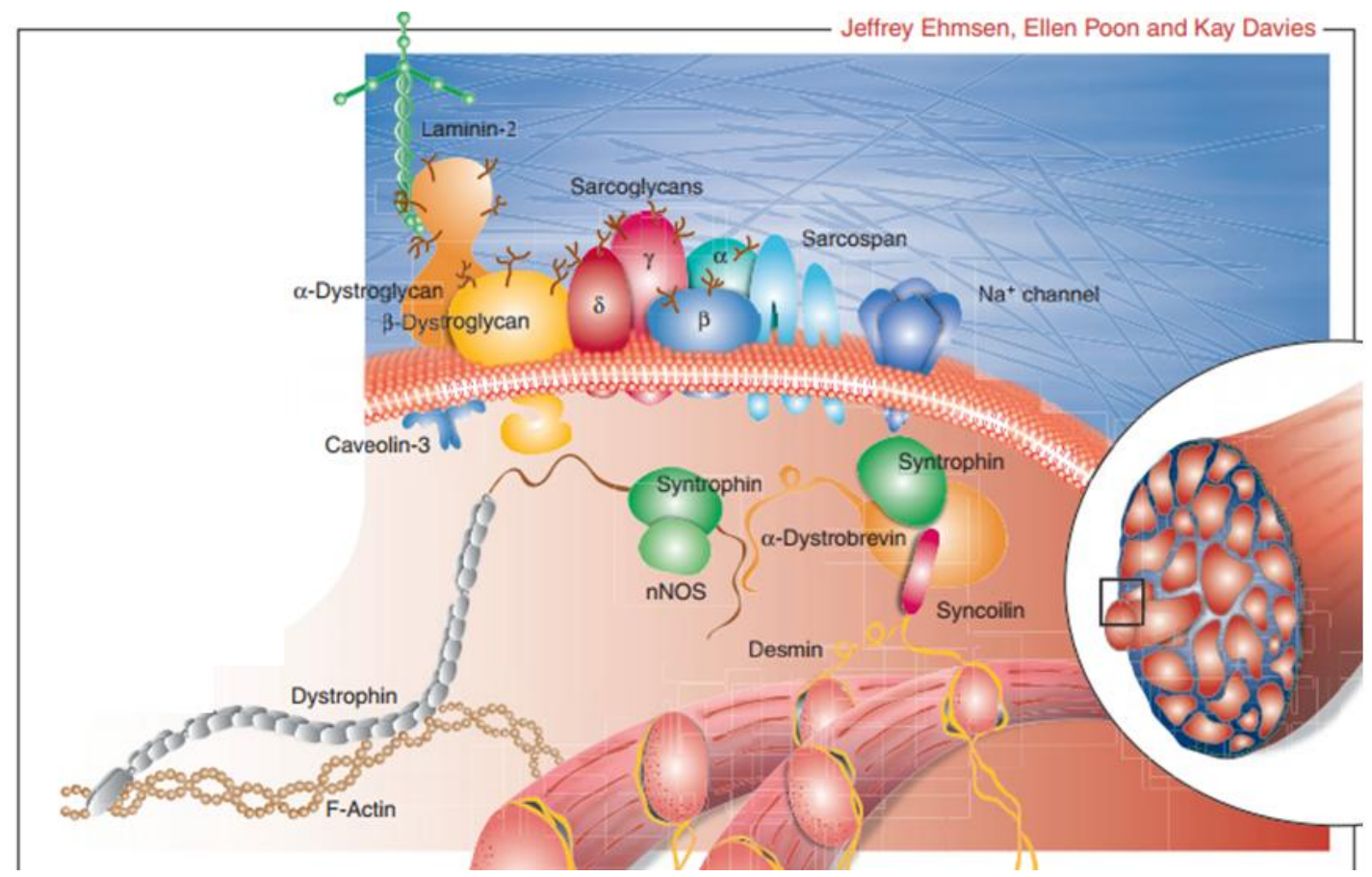

Figura 5: Complexo distrofina-glicoproteínas associadas. Modificado de: Ehmsen et al., 2002 . 


\subsubsection{Distrofia Muscular de Duchenne}

A Distrofia Muscular de Duchenne (DMD) é a mais comum entre as doenças neuromusculares, atingindo cerca de 1 em cada 3600 meninos nascidos em todo o mundo (Chung et al., 2015). Sua forma alélica, a distrofia muscular de Becker (BMD), é cerca de 10 vezes mais rara, e os pacientes apresentam fenótipo mais brando (O’Brien \& Kunkel, 2001). O gene da distrofina está localizado no braço curto do cromossomo X e mutações que causam DMD resultam na deficiência da proteína distrofina no músculo. Estas mutações são, em $60 \%$ dos casos, deleções, além de duplicações e mutações de ponto nos demais casos. A perda funcional dessa proteína de $427 \mathrm{kDa}$ provoca degeneração muscular acentuada devido à instabilidade estrutural no complexo distrofina-glicoproteínas associadas. As manifestações clínicas começam entre 4 e 5 anos de idade, o confinamento à cadeira de rodas ocorre entre 8 e 10 anos de idade e a sobrevivência em geral não ultrapassa a terceira década de vida (Hoffman \& Dressman, 2001).

\subsubsection{Distrofia Muscular Congênita 1D}

Formas de distrofias congênitas podem ser causadas por genes envolvidos no processo de glicosilação de proteínas musculares. A Distrofia Muscular Congênita 1D (CMD1D) é causada por mutações no gene da glicosiltransferase LARGE, responsável pela glicosilação da proteína $\alpha$-distroglicana (Figura 6), membro essencial da formação e funcionamento do complexo CDG muscular. Clinicamente, o paciente afetado por CMD1D apresenta fraqueza desde o nascimento ou no início da infância. Crianças afetadas geralmente apresentam baixo tônus muscular e poucos movimentos espontâneos, também podem apresentar atraso ou interrupção do desenvolvimento motor, juntamente com rigidez articular e da coluna vertebral (Brockington et al., 2005; Muntoni et al., 2008). A fraqueza muscular pode estabilizar a curto prazo, entretanto, o processo de degeneração muscular é progressivo, com o tempo levando à maior fraqueza, contraturas articulares, deformidades da coluna vertebral e comprometimento respiratório, afetando a qualidade e o tempo de vida dos pacientes. Portanto, o estudo da via de glicosilação de proteínas musculares se tornou muito importante na compreensão de novos mecanismos causadores de doenças neuromusculares humanas (Vainzof et al., 2008). 

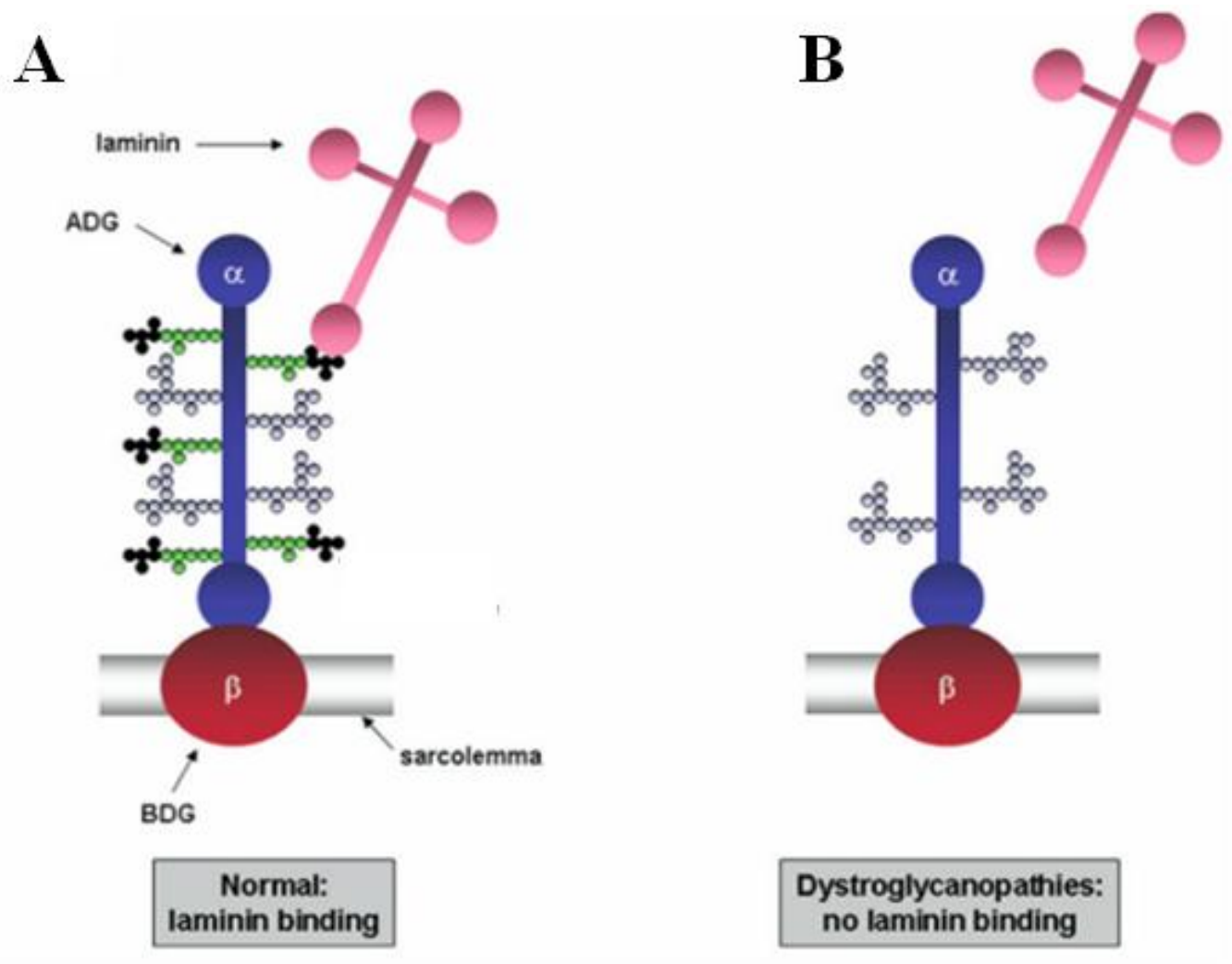

Figura 6: Glicosilação da alpha distroglicana (ADG) acontece pela glicosiltransferase LARGE. A hipoglicosilação ocasiona a deficiência na ligação entre as proteínas do Complexo CDG e as proteínas da matriz extracelular. (A) Glicosilação normal. (B) Hipoglicosilação. Modificado de: Muntoni et al, 2008.

\subsection{Células Satélite nas Distrofias Musculares}

O músculo distrófico é persistentemente lesionado e o processo regenerativo é consistentemente ativado, recrutando SCs em taxas mais elevadas do que no músculo normal. Apesar deste recrutamento e ativação das SCs, o músculo distrófico não consegue se regenerar por completo, e as fibras musculares acabam sendo substituídas por tecido conjuntivo e adiposo (Wallace e Mcnally, 2009). Portanto, nestes casos, as SCs não conseguem executar uma regeneração completa. Neste cenário, diferentes hipóteses são propostas para explicar a degeneração muscular progressiva que ocorre em pacientes portadores de mutações em diferentes genes importantes para estrutura e função muscular (Wallace e Mcnally, 2009; Rahimov e Kunkel, 2013).

Uma hipótese é de que a diferenciação de mioblastos pode não ser adequada, como mostrado em estudos anteriores com pacientes com DMD (Delaporte et al., 1984; Jasmin et al., 1984). Em alguns tipos de distrofia muscular, o gene mutado não é 
expresso em SCs e, portanto, não influencia diretamente na sua função (Morgan e Zammit, 2010). No entanto, também há evidências de que a própria mutação primária pode prejudicar a função das SCs, reduzindo seu número e causando senescência prematura e as colocando como atuantes diretas no quadro degenerativo da doença (Kudryashova et al., 2012). Um estudo recente mostrou que a distrofina é expressa por SCs e desempenha um papel essencial na regulação de sua polaridade e divisão assimétrica. $\mathrm{Na}$ ausência de distrofina, há uma redução na quantidade de divisões assimétricas e um aumento no número de divisões anormais, que levam à diminuição da quantidade de progenitores miogênicos e, portanto, uma falha na regeneração muscular (Dumont et al., 2015).

Outra hipótese é de que repetidos ciclos de replicação levariam à senescência das células pelo encurtamento dos telômeros, o que foi observado em pacientes com DMD e Distrofia Muscular de Cinturas tipo 2C (LGMD2C) (Decary et al., 1997; Decary et al., 2000) e também em camundongos $D m d^{m d x}$ (Lund et al., 2007).

Por fim, no camundongo modelo para Distrofia Muscular Congênita 1D (DMC1D) Large $e^{m y d}$, foi encontrado um número aumentado de SCs associadas às fibras musculares recém isoladas, se comparadas ao controle. Apesar disso, neste modelo existe um processo de degeneração bastante acentuado com uma lâmina basal composta por excesso de fibronectina e colágeno, atuando como um obstáculo à proliferação correta das SCs. Neste modelo, a capacidade proliferativa das SCs foi vista como sendo reduzida enquanto permaneciam ligadas às fibras, mas após o isolamento total, elas se proliferaram e se diferenciaram em níveis comparáveis aos do controle, indicando um papel importante do nicho para a função da célula-tronco (Ross et al., 2012).

\subsection{Modelos Animais}

O uso de modelos animais como camundongos, cães e gatos é de extrema importância para o melhor entendimento das doenças genéticas humanas e para a investigação de terapias experimentais (Vainzof et al., 2008). Para o estudo da distrofia muscular do tipo Duchenne, por exemplo, é possível utilizar o modelo de camundongo $D m d^{m d x}$, linhagem deficiente em distrofina devido a uma mutação de ponto no exon 23 do gene, que forma um códon de parada prematura. Como nos pacientes, o músculo de camundongos $D m d^{m d x}$ é afetado por degeneração e necrose e é um excelente modelo para testes moleculares. Entretanto, este modelo exibe um quadro clínico mais brando, 
sem fraqueza muscular evidente nem redução na expectativa de vida, pois apresenta uma grande capacidade de regeneração muscular (Bulfield et al., 1984).

Um modelo murino importante para o estudo de defeito de glicosilação da $\alpha$ distroglicana é o camundongo Large $e^{m y d}$, que apresenta uma mutação espontânea no gene que codifica a glicosiltransferase LARGE. O camundongo afetado manifesta uma distrofia muscular muito grave e com padrão de herança autossômico recessivo. Esta mutação é uma deleção de $100 \mathrm{~kb}$, que engloba os exons de 4 a 7 do gene Large, localizado no cromossomo 8 em camundongos e $22 \mathrm{em}$ humanos. O mRNA resultante da deleção possui um códon de terminação prematuro, anterior ao primeiro dos dois domínios catalíticos e leva ao surgimento de uma proteína truncada. O gene Large codifica uma glicosiltransferase (com 98\% de identidade com a sequência dos aminoácidos em humanos) (Grewal e Hewitt, 2002; Browning et al., 2005) e defeitos nesta proteína levam à alteração da glicosilação da $\alpha$-distroglicana e consequente desestruturação do CDG. Desta forma, impossibilita sua correta ligação aos componentes da matriz extracelular e às proteínas internas da fibra muscular, o que leva a degeneração muscular e ao padrão distrófico observado no músculo (Browning et al., 2005; Vainzof et al., 2008).

Com o objetivo de obter um modelo animal para DMD com um fenótipo mais grave e que simulasse melhor o que acontece com os pacientes afetados, bem como para estudar o papel das duas proteínas no quadro de distrofia, produzimos em nosso laboratório um camundongo duplo mutante para as mutações dos camundongos $D m d^{m d x}$ e Large $e^{m y d}$, gerando o camundongo Dmd $d^{m d x} / \operatorname{Large}^{m y d}$. Este camundongo possui um quadro de distrofia muscular bem grave, com atraso no crescimento e desenvolvimento e incapacidade de reprodução. Possui expectativa de vida de aproximadamente 24 semanas, enquanto a expectativa de vida do camundongo Large $e^{\text {myd }}$ é de 39 semanas e do camundongo $D m d^{m d x}$ é de cerca de 2 anos (Martins et al., 2013). Desta forma, este animal possibilita estudar o músculo com padrão de degeneração grave como o do

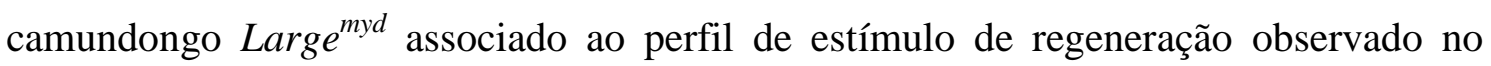
$D m d^{m d x}$. 


\subsection{Objetivos}

\subsubsection{Objetivo geral}

O objetivo desse projeto consiste em analisar as SCs em diferentes modelos murinos para distrofias musculares com defeitos gênicos primários distintos, para entendermos o comportamento e o funcionamento destas células de acordo com o ambiente onde estão inseridas.

\subsubsection{Objetivos específicos}

a) Análise quantitativa da expressão de proteínas relacionadas às SCs e à diferenciação de células musculares.

b) Análise quantitativa da expressão de genes relacionados às SCs e à diferenciação de células musculares.

c) Análise de estágio de proliferação celular do músculo.

d) Caracterização histológica de SCs e do nível de degeneração e regeneração do músculo distrófico em cada modelo.

e) Comparação de alterações moleculares com as observações histológicas. 


\section{Capítulo 2 - Metodologia Geral}

\subsection{Animais}

Para análise histológica e de expressão gênica e proteica, foram examinados músculos de camundongos machos (preferencialmente) com 12-14 semanas de idade. As linhagens utilizadas foram $D M D^{m d x}$ (seis machos), Large $e^{m y d}$ (seis machos), C57Bl/6 (WT) (seis machos) e duplo mutante $D M D^{m d x} /$ Large $^{m y d}$ (três machos e três fêmeas, devido a dificuldade de obtenção). Para o ensaio de citometria de fluxo, foram utilizadas três linhagens: $D M D^{m d x}$ (cinco machos), Large ${ }^{m y d}$ (cinco machos), C57Bl/6 (WT) (cinco machos) com 12-14 semanas de idade. Durante os experimentos, os animais foram criados e mantidos em temperatura e luz controladas no Biotério do Centro de Estudos do Genoma Humano e Células Tronco (CEGH-CEL). Todos os experimentos foram realizados de acordo com o comitê de ética de uso animal do Instituto de Biociências da Universidade de São Paulo (protocolo número 246/2016).

\subsection{Coleta do tecido}

Os animais foram pesados e em seguida eutanasiados em câmara de $\mathrm{CO}_{2}$ de acordo com as diretrizes do Conselho Nacional de Controle de Experimentação Animal (CONCEA). Após serem eutanasiados, ambos os músculos gastrocnêmios foram coletados e congelados em nitrogênio líquido para estudo de expressão gênica, padrões histológicos e quantificação de proteínas. Para análise de tecido por citometria de fluxo, ambos os gastrocnêmios foram coletados e dissociados mecanicamente para obtenção de células únicas.

\subsection{Estudo de expressão gênica (PCR em tempo real)}

As amostras foram previamente maceradas e o RNA total foi extraído utilizando o RNeasy Microarray Tissue Mini Kit (Qiagen) e tratado com rDNase (Macherey-Nagel), segundo as instruções do fabricante. A análise da integridade e quantidade do RNA foi realizada em espectrofotômetro Nanodrop1000 ${ }^{\mathrm{TM}}$ (Thermo Fisher Scientific). O RNA de cada amostra teve, ainda, sua integridade analisada em gel de agarose $1 \%$ utilizando o protocolo descrito por Aranda et al., (2012). 
Para a síntese de cDNA, foi utilizado $1 \mu \mathrm{g}$ de RNA total, $0,1 \mu \mathrm{l}$ de random primer, $0,5 \mu 1$ de oligo dT, $1 \mu 1$ de dNTP mix $(10 \mathrm{mM})$ e água DEPC até o volume de $12 \mu \mathrm{l}$. Essa mistura foi deixada a $65^{\circ} \mathrm{C}$ no termociclador por 10 minutos. Em seguida, adicionou-se $4 \mu \mathrm{l}$ de tampão Tris- $\mathrm{HCl}(50 \mathrm{mM}) \mathrm{pH} 8,3 ; 75 \mathrm{mM}$ de $\mathrm{KCl} ; 3 \mathrm{mM}$ de $\mathrm{MgCl} 2$ (5x First Strand Buffer); $2 \mu \mathrm{l}$ de DTT $(0,1 \mathrm{mM})$ e $1 \mu \mathrm{l}$ de RNAse OUT (40U/ $\mu 1)$, para incubação no termociclador a $37^{\circ} \mathrm{C}$ por 2 minutos. Após retirar as amostras, foram adicionados $1 \mu 1$ de transcriptase reversa MMLV e nova incubação a $25^{\circ} \mathrm{C}$ por 10 minutos, em seguida a $37^{\circ} \mathrm{C}$ por 50 minutos e, por fim, a $7^{\circ} \mathrm{C}$ por 15 minutos.

As reações de PCR em tempo real (qRT-PCR) foram aplicadas em triplicata em placa de 96 poços, $5 \mu 1$ de água DEPC, $2 \mu 1$ de cada primer do gene de interesse, $10 \mu 1$ FastStart Universal SYBR Green Master (Rox) (Roche) e $1 \mu 1$ de cDNA (diluição 1:10 em água RNase free), num volume total de $20 \mu \mathrm{L}$. Cada placa foi corrida no termociclador para Real-Time 7500 Fast da Applied Biosystems/Life com o seguinte programa: $50^{\circ} \mathrm{C}$ por 2 minutos, $95^{\circ} \mathrm{C}$ por 10 minutos, 40 ciclos a $95^{\circ} \mathrm{C}$ por 15 segundos e $60^{\circ} \mathrm{C}$ por 1 minuto.

Para a quantificação da expressão dos fatores miogênicos de interesse foram utilizados os genes: MyoD, Myf5, Miogenina, Pax7 além de Tbp como gene endógeno de referência para a normalização dos dados, utilizando os primers discriminados na (Tabela 1).

Tabela 1: Primers murinos

\begin{tabular}{|c|c|c|}
\hline Gene & Forward sequence & Reverse sequence \\
\hline $\boldsymbol{P a x} 7$ & GAGTTCGATTAGCCGAGTGC & GAGTTCGATTAGCCGAGTGC \\
\hline $\boldsymbol{M y} \boldsymbol{f 5}$ & GAAGGTCAACCAAGCTTTCG & GCTCTCAATGTAGCGGATGG \\
\hline $\boldsymbol{M y o \boldsymbol { D }}$ & TACAGTGGCGACTCAGATGC & TAGTAGGCGGTGTCGTAGCC \\
\hline $\boldsymbol{M i o g e n i n \boldsymbol { a }}$ & CAGTACATTGAGCGCCTACAG & GGACCGAACTCCAGTGCAT \\
\hline $\boldsymbol{T b p}$ & TGCACAGGAGCCAAGAGTGAA & CACATCACAGCTCCCCACCA \\
\hline
\end{tabular}


Previamente à realização dos procedimentos de qRT-PCR, as concentrações ideais dos primers foram determinadas, bem como os procedimentos de curva padrão para verificação da eficiência de amplificação da reação e o threshold de cada gene estudado foram realizados (Tabela 2).

Tabela 2: Valores da padronização dos primers murinos

\begin{tabular}{|c|c|c|c|c|}
\hline Gene & Threshold & Slope & $\mathbf{R}^{\mathbf{2}}$ & Eff\% \\
\hline Pax7 & 0,238357 & $-3,339$ & 0.99 & 99.284 \\
\hline Myf5 & 0,539199 & $-3,212$ & 0,99 & 104,81 \\
\hline MyoD & 0,580735 & $-3,308$ & 0,99 & 100,601 \\
\hline Miogenin & 0,345441 & $-3,347$ & 0,99 & 98,972 \\
\hline Tbp & 0,320734 & $-3,244$ & 0,99 & 103,34 \\
\hline
\end{tabular}

\subsection{Estudo quantitativo de proteínas por Western Blot}

Foram adicionados $250-400 \mu 1$ de tampão RIPA (Sigma-Aldrich) ao tecido que, posteriormente, foi macerado com pistilo e incubado por 30 minutos no gelo, seguido por centrifugação a $10000 \mathrm{G}$ durante 20 minutos a $4^{\circ} \mathrm{C}$. Por fim, coletou-se o sobrenadante. Em seguida, as proteínas extraídas foram quantificadas com o uso do kit Pierce BCA Assay (Thermo Scientific), seguindo informações do fabricante.

Amostras foram aquecidas a $100^{\circ} \mathrm{C}$ por 2 minutos, centrifugadas a $14000 \mathrm{G}$ por 2 minutos e aplicadas ao gel com gradiente de concentração de 4-15\% MiniPROTEAN® TGX ${ }^{\mathrm{TM}}$ Gel, 15 well, $15 \mu 1$ (BioRad). A corrida foi realizada sob voltagem de $100 \mathrm{~V}$, por 2 a 3 horas. Após a eletroforese, as proteínas foram transferidas para uma membrana de nitrocelulose utilizando iBlot ${ }^{\circledR}$ Gel Transfer Device (Invitrogen) durante 7 minutos. A membrana foi secada, lavada com TTBS, corada com Ponceau (Sigma-Aldrich) e fotografada. Posteriormente, a membrana foi lavada com TTBS e bloqueada com leite 5\% por uma hora. Após o bloqueio, a membrana foi submetida à incubação com anticorpos primários, seguindo as diluições sugeridas pelos fabricantes. As proteínas analisadas foram PAX7 e MYOG. Os anticorpos primários utilizados foram PAX7 (1:1000 Novus Biologicals; nbp1 69130) e Myogenin (1:250 abcam; 15232). 
Os anticorpos secundários utilizados são conjugados à horseradish peroxidase, as membranas foram reveladas utilizando $\mathrm{o}$ reagente Novex ${ }^{\mathrm{TM}}$ ECL Chemiluminescent Substrate Reagent kit (Invitrogen) e imagens foram obtidas com uso de foto-documentador (ImageQuant, GE). As bandas obtidas foram quantificadas por densitometria utilizando-se o software ImageQuant TL (GE). Para reação com o controle endógeno, as membranas foram incubadas com tampão de stripping (Thermo Fisher Scientific) e posteriormente incubadas com anticorpo para análise do endógeno GAPDH (1:1000 Cell Signaling 2118).

\subsection{Estudo de Ciclo Celular}

O ciclo celular foi analisado utilizando o método de coloração com iodeto de propídio (PI) Guava Cell Cycle (Millipore). O iodeto de propídio é intercalante fluorescente de DNA e permite a visualização do estágio do ciclo celular das células analisadas com base na quantidade de DNA existente em cada célula. As células em repouso (G0/G1) contêm duas cópias de cada cromossomo. As células que estão na fase $\mathrm{S}$ emitem uma intensidade de fluorescência aumentada, pois estão sintetizando o DNA. Quando todo o DNA cromossômico está em dobro (fase G2/M), as células fluorescem com o dobro da intensidade da população inicial. Para a realização do experimento, os músculos gastrocnêmio foram coletados e mecanicamente dissociados utilizando placas de petri e bisturis. O produto da dissociação mecânica foi passado através de uma sequência de peneiras de $70 \mu \mathrm{m}$ e $40 \mu \mathrm{m}$ respectivamente para obtenção de células únicas. Um total de 2 x $10^{5}$ células foram fixadas com etanol $70 \%$ gelado durante 12 horas a $4^{\circ} \mathrm{C}$. As células foram então lavadas com PBS e incubadas no escuro com $200 \mu \mathrm{l}$ de Reagente Guava Cell Cycle Reagent for Flow Cytometry (Merck Millippore) durante 30 minutos à temperatura ambiente. As amostras foram analisadas por citometria de fluxo no citômetro Aria (BD Biosciences).

\subsection{Análise Histológica}

Os músculos foram fixados com TissueTek O.C.T (Quiagen) em blocos de cortiça e envoltos por talco para crioproteção e congelados em nitrogênio líquido. $\mathrm{O}$ 
tecido congelado foi cortado em criostato (Microm HM 505E) à temperatura de $-25^{\circ} \mathrm{C}$ com cortes de $6 \mu \mathrm{m}$ de espessura, de modo que as fibras se apresentassem em disposição transversal na lâmina, que foi previamente coberta por polilisina. As lâminas foram mantidas refrigeradas a $-70^{\circ} \mathrm{C}$ até o momento da sua utilização.

\subsection{Estudo anatomopatológico}

Para a coloração com HE, as lâminas foram coradas com hematoxilina por 10 minutos e lavadas em água corrente por 10 minutos. Em seguida, foram coradas com eosina por 3 minutos e lavadas para eliminar o excesso de corante. Os cortes foram fixados em ácido acético, desidratados em concentrações crescentes de álcool etílico e xilol e montados com Bálsamo do Canadá. A variação no calibre pode ser avaliada nos músculos dos diferentes modelos animais. A média no valor do diâmetro das fibras musculares de cada grupo foi obtida $(\mathrm{n}=100)$. Os dados apresentados foram a média de cada grupo experimental, bem como o coeficiente de variação calculado de acordo com a fórmula: desvio padrão x $1000 \div$ média do grupo (Victor Dubowitz, 2013). Os cortes histológicos foram observados e fotografados em microscópio de luz (Zeiss).

\subsection{Estudo do tecido conjuntivo}

Foi utilizada a coloração de Picrossírius, que indica infiltração de tecido conjuntivo pelo aumento de colágeno entre as fibras musculares. As lâminas foram imersas em fixador Bouin por 20 minutos e lavadas em água corrente. Os cortes foram então corados com solução de Picrossírius (Sirius red 0,2g e solução aquosa saturada de ácido pícrico $100 \mathrm{ml}$ ) por 15 minutos a $1 \mathrm{~h}$; durante este tempo, observou-se até que as lâminas atingissem uma coloração homogênea. As lâminas foram lavadas, desidratadas em concentrações crescentes de álcool e xilol e montadas com bálsamo do Canadá. Com o auxílio do software ImageJ, foi quantificada a porcentagem de área positiva ao colágeno, marcado em vermelho, em relação à área total do corte (4-5 micrografias de diferentes regiões de cada corte histológico, 5-6 animais/grupo experimental). 


\subsection{Análise de fibras musculares em regeneração por imunofluorescência}

Para identificar fibras musculares recém-diferenciadas, utilizamos o anticorpo contra miosina de desenvolvimento de cadeia pesada (dMHC), uma proteína sarcomérica que indica áreas de regeneração marcadas em vermelho. As lâminas foram cobertas com PBS e incubadas overnight com o anticorpo primário mouse anti-dMHC (diluição de 1:30; Vector; VP-M664) e rabbit anti-laminina (1:50; Dako; Z0097), lavadas e, em seguida, incubadas por $1 \mathrm{~h}$ com anticorpo secundário sheep anti-mouse IgG conjugado com Cy3 (1:100; Sigma; C2181) e donkey anti-rabbit IgG conjugado com FITC (1:100; Amersham; N1034), respectivamente. Após lavagem com PBS, as lâminas foram montadas com Vectashield contendo DAPI para visualização dos núcleos. A análise dos cortes histológicos foi realizada em microscópio de fluorescência (Zeiss). A formação de novas fibras foi quantificada pela contagem de fibras marcadas em vermelho, dMHC+, em relação ao número total de fibras (4 campos, $n=5-6$ animais/grupo experimental). Também foi realizada a medição do diâmetro das fibras $\mathrm{dMHC}+$, nos animais que apresentaram fibras dMHC positivas, para a obtenção do coeficiente de variação (Victor Dubowitz, 2013).

\subsection{Análise estatística}

A diferença entre dois grupos foi medida utilizando o teste estatístico não paramétrico Mann-Whittney. A análise estatística foi calculada utilizando o software Minitab e o valor de $\mathrm{p}<0,05$ foi considerado significante. 


\section{Capítulo 3}

Satellite Cells Analysis in Different Murine Models from Muscular Dystrophies

Antonio F. Ribeiro Junior ${ }^{1}$, Renata Ishiba ${ }^{1}$, Stephanie A. Fernandes ${ }^{1}$, Danielle A. Guerrieri ${ }^{1}$, André L. F dos $\operatorname{Santos}^{1}$ Lucas S e Souza and Mariz Vainzof ${ }^{1}$.

\section{Affiliations}

1 Human Genome and Stem-cell Research Center, Biosciences Institute, University of São Paulo, São Paulo, Brazil.

\section{Corresponding author}

Mariz Vainzof

Human Genome and Stem-cell Research Center, University of São

Paulo Rua do Matão, Travessa 13, nº 106

São Paulo, SP, 05508-090,

Brazil

mvainzof@usp.br 


\section{Abstract}

Muscle tissue has a high regeneration capacity after injury, which is directly linked to satellite cells (SCs). These cells are the main stem cells of the muscle and also have a key role in muscle development in embryogenesis. Although quiescent in normal adult muscles, SCs can be activated by specific signals upon muscle injury. In diseases characterized by chronic degeneration process, such as muscular dystrophies, the SCs are constantly activated, leading to depletion of the SC pool and consequent failure of the regenerative process. We studied muscle SCs in the mouse dystrophic strains $D M D^{m d x}$, Large $e^{m y d}$, $D M D^{m d x} /$ Large $e^{m y d}$, comparing to wild-type mice, with the main objective to evaluate SCs behavior in dystrophic muscles with different degrees of histopathological degeneration.

Gene and protein expression of transcription factors related to SCs were studied in the muscle, and the results were compared to regenerating and degenerating histopathological characteristics and proliferative state of muscle cells. Our results showed that the dystrophic muscle retains its satellite cells pool, expressing PAX7, an important muscle factor for self-renewal of the SCs pool, at similar levels in all dystrophic strains and wild-type. Dystrophic muscle single cells presented a higher proportion of proliferating cells, as observed by the analysis of cell cycle markers in dissociated gastrocnemius muscle, with a greater number of cells in the G2/M phase. The cascade of regeneration genes is activated in the dystrophic muscle, with high levels of expression of muscle regenerating factors, such as MYOD and Myogenin. Dystrophic muscle retains the ability to form new fibers, as observed by a significant number of new fibers expressing $\mathrm{dMHC}$ in all dystrophic strains. However, these new fibers show incomplete maturation characteristics, such as small size and no variation in fiber caliber, which could be determinant for its dysfunction. Muscle degeneration is intense in spite of regeneration, with significant more connective tissue infiltration in dystrophic mice than wild-type mice. In conclusion, our findings suggest that dystrophic muscles, independently of the degree of degeneration, retain the pool of satellite cells with proliferating capacity and ready to respond to regenerating stimuli. On the other hand, the maturation of these new fibers is incomplete and do not prevent the degeneration of the muscle. 


\section{Resumo}

O tecido muscular tem uma alta capacidade de regeneração após lesão, que está diretamente ligada à presença de células satélite (SCs). Essas células são as principais células-tronco do músculo e também têm um papel fundamental no desenvolvimento muscular na embriogênese. Embora quiescentes nos músculos adultos normais, as SCs podem ser ativadas por sinais específicos após lesão muscular. Em doenças caracterizadas por processo de degeneração crônica, como distrofias musculares, as SCs são constantemente ativadas, e esta condição pode levar à depleção do pool de SCs e consequente falha no processo regenerativo. Nós estudamos as SCs musculares nas linhagens distróficas murinas $D M D^{m d x}$, Large $e^{m y d}, D M D^{m d x} /$ Large $e^{m y d}$, em comparação a camundongos normais, com o principal objetivo de avaliar o comportamento das SCs em músculos distróficos com diferentes graus de degeneração histopatológica. A expressão de genes e proteínas de fatores de transcrição relacionados a SCs foram estudadas no músculo, e os resultados foram comparados com características histológicas de regeneração e degeneração e estado de proliferação de células musculares. Nossos resultados mostraram que o músculo distrófico mantém seu pool de células satélite, expressando PAX7, um importante fator muscular para autorrenovação do pool de SCs, em níveis semelhantes em todas as linhagens distróficas e controle normal. As células isoladas de músculo distrófico apresentaram uma maior proporção de células em proliferação, como observado pela análise dos marcadores de ciclo celular no músculo gastrocnêmio dissociado, com maior número de células na fase G2/M. A cascata de genes de regeneração é ativada no músculo distrófico, com altos níveis de expressão de fatores de regeneração muscular, como MYOD e Myogenin. O músculo distrófico mantém a capacidade de formar novas fibras, observada por um número significativo de fibras recém-formadas, que expressam dMHC, em todas as linhagens analisadas. No entanto, essas novas fibras mostram características de maturação incompletas, como tamanho pequeno e pouca variação em seu calibre, que pode ser determinante para sua disfunção. A degeneração muscular é intensa apesar da regeneração, com infiltração significativa de tecido conjuntivo em camundongos distróficos. Em conclusão, nossos achados sugerem que os músculos distróficos, independentemente do grau de degeneração, mantêm o pool de células satélite com capacidade proliferativa e estão prontos para responder aos estímulos regenerativos. Por outro lado, a maturação dessas novas fibras é incompleta e não previne a degeneração do músculo. 


\section{Introduction}

Skeletal muscles represent about half of the total body weight and are responsible for almost all voluntary movements. Muscle tissue has a high regeneration capacity after injury, which is directly linked to satellite cells (SCs). These cells are the main stem cells of the muscle and also have a key role in muscle development in embryogenesis (Chargé e Rudnicki, 2004; Bentzinger et al., 2012). SC localization is associated with the sarcolemma, residing between the basal lamina and the muscle membrane (Mauro, 1961). Although quiescent in normal adult muscles, SCs can be activated by specific signals upon muscle injury. In diseases characterized by chronic degeneration process, like muscular dystrophies, the SCs are constantly activated, and this condition can lead to depletion of the SC pool and consequent failure of the regenerative process (Heslop et al., 2000).

Muscular dystrophies are a heterogeneous group of genetic diseases that cause a progressive loss of motor ability. Defects in components of the dystrophin glycoprotein complex (DGC) are responsible for different forms of muscular dystrophies. The DGC complex forms the link between myofiber cytoskeleton proteins and the extracellular matrix, providing mechanical support to sarcolemma during myofiber contraction (Yoshida e Ozawa, 1990; Sunada e Campbell, 1995).

Mutations in the dystrophin gene lead to Duchenne/Becker Muscular Dystrophies (DMD/BMD) (Hoffman et al., 1987). The DGC proteins are linked to extracellular matrix proteins by post-translational glycosylation of the $\alpha$-dystroglycan $(\alpha-D G)$ protein. Mutations in the $L A R G E$ gene, that encodes a putative glycosyltransferase, lead to Congenital Muscular Dystrophy type 1D (Brockington et al., 2005; Townsend, 2014).

Identified in nature or generated in laboratory, animal models are an important tool to study neuromuscular disorders. These models generally present physiological alterations observed in human patients and can be used for pathophysiological studies and therapy testing (Vainzof et al., 2008). A good genetic and biochemical model for DMD is $D m d^{m d x}$ mice that bears a non-sense point mutation in exon 23 of the dystrophin gene, which causes lack of this protein in the skeletal muscle. Regardless of total protein deficiency, these mice show a mild phenotype, with comparatively moderate muscle pathology. Muscle histopathology shows great number of regenerating 
fibers, variation in fiber size and the presence of central nuclei. Differently from human DMD patients, muscle degeneration in the $D m d^{m d x}$ mouse is followed by a significant regeneration (Dangain e Vrbova, 1984; Sicinski et al., 1989). A model for Congenital Muscular Dystrophy type 1D is the myodystrophy Large ${ }^{\text {myd }}$ mouse, which harbors a mutation in the gene Large, which encodes a glycosyltransferase that presumably alters

the glycosylation of $\alpha$-DG. Large ${ }^{\text {myd }}$ mutant mice develop a progressive myopathy, with a maximum lifespan of 39 weeks. Muscle histopathology includes degeneration, loss of striation, variation in fiber size and the presence of central nuclei (Grewal e Hewitt, 2002).

With the goal of obtaining an animal model for DMD with a severe phenotype, more similar to affected DMD patients and to better understand the interplay between the lack of dystrophin and LARGE glycosyltransferase in muscle function, our Lab bred $D m d^{m d x}$ and Large $e^{m y d}$ mice, generating double-mutant animals deficient in these two proteins. The new $D m d^{m d x} / \operatorname{Large}^{m y d}$ mouse model has a severe phenotype with delayed growth and development and inability to reproduce. In addition to the important physiopathological aspects of the effects of these two mutations in muscle formation and function, this model has an important application for testing therapies, integrating functional, molecular and protein studies (Martins et al., 2013).

Here, we aimed to understand the behavior of SCs in dystrophic muscles with different degrees of muscle degeneration and how the dystrophic microenvironment can affect SCs. To achieve our aims, gene and protein expression of transcription factors related to SCs were studied in the muscle of different mouse models for muscular dystrophies, and the results were compared to regenerating and degenerating characteristics and proliferative state of muscle cells. Our findings indicate that the SCs pool of the studied dystrophic strains maintain their proliferating capacity and these cells can contribute to muscle regeneration and new fiber formation. On the other hand, newly formed fibers cannot mature to reach a functional fiber size and the dystrophic microenvironment seems to contribute to SCs dysfunction.

\section{Materials and methods}

Animals

For histological, gene expression and protein analyses, we examined 
gastrocnemius muscles of male mice with 12-14 weeks of age. The studied strains were: $D M D^{m d x}$ (six males), Large $e^{m y d}$ (six males), C57Bl/6 (six males) and double mutant $D M D^{m d x} / \operatorname{Large}^{m y d}$ (three males and three females, due to the difficulty of obtainment). For flow cytometry assays, we used five males with 12-14 weeks of age of the $D M D^{m d x}$, Large $^{\text {myd }}$ and $C 57 B l / 6$ strains.

During the experiments, animals were bred and housed in controlled temperature and light in the animal house of the Human Genome and Stem Cell Research Center (HUG-CELL). All experiments were performed in accordance with the ethical committee of animal use of the Institute of Bioscience of University of São Paulo (protocol number 246/2016).

\section{Tissue collection}

After euthanasia, the gastrocnemius muscle were collected and frozen in liquid nitrogen to study gene expression, histological patterns and protein quantification. For muscle single cell analysis through flow cytometry, both gastrocnemius were collected from each animal, and were mechanically dissociated to obtain single cells.

RNA extraction, cDNA synthesis and $q R T-P C R$

RNA extraction from frozen muscles was performed using the RNeasy Microarray Tissue Mini Kit (Qiagen). RNA was solubilized in RNase-free water $\left(A m b i o n{ }^{\mathrm{TM}}\right.$ ) and quantified in a Nanodrop spectrophotometer (Thermo Fisher Scientific). The cDNA synthesis was performed using $1 \mu \mathrm{g}$ of total RNA according to the M-MLV protocol (Invitrogen). Samples were amplified in triplicates using the MasterMix containing Sybr Green (Applied Biosystems) and primers (detailed in Table 1) on a thermocycler 7500 Fast (Applied Biosystems). The fold-change was obtained by the $2^{-\Delta \Delta \mathrm{CT}}$ method, with $T b p$ gene as normalizer. 
Table 1: Primers sequences

\begin{tabular}{|c|c|c|}
\hline Gene & Forward sequence & Reverse sequence \\
\hline $\boldsymbol{P a x} 7$ & GAGTTCGATTAGCCGAGTGC & GAGTTCGATTAGCCGAGTGC \\
\hline $\boldsymbol{M y} \boldsymbol{f 5}$ & CTGTCTGGTCCCGAAAGAAC & GACGTGATCCGATCCACAATG \\
\hline $\boldsymbol{M y} \boldsymbol{D} \boldsymbol{D}$ & TACAGTGGCGACTCAGATGC & TAGGCGGTGTCGTAGCC \\
\hline $\boldsymbol{M i o g e n i n \boldsymbol { a }}$ & CAGTACATTGAGCGCCTACAG & GGACCGAACTCCAGTGCAT \\
\hline $\boldsymbol{T b p}$ & TGCACAGGAGCCAAGAGTGAA & CACATCACAGCTCCCCACCA \\
\hline
\end{tabular}

Protein analysis

Frozen tissue samples from gastrocnemius muscles were homogenized in RIPA buffer (Sigma-Aldrich) supplemented with $1 \%$ of protease inhibitors and phosphatase inhibitors (Sigma-Aldrich). Samples were kept on ice for 30 minutes and afterwards centrifuged at $16.000 \mathrm{G}$ for $20 \mathrm{~min}$ at $4^{\circ} \mathrm{C}$, followed by protein quantification using the kit Pierce BCA Assay (Thermo Scientific). Homogenized samples with 30 $\mu$ g were separated by SDS-PAGE in 4-15\% Mini-PROTEAN® TGX ${ }^{\mathrm{TM}}$ Gels (BioRad) and transferred to nitrocellulose membranes using iBlot ${ }^{\circledR}$ Gel Tranfer Device (Invitrogen) for 7 minutes. The obtained membranes were probed using the antibodies: PAX7 (1:1000 Novus Biologicals; nbp1 - 69130) e Myogenin (1:250 abcam; 15232). The membranes were then incubated with the appropriated secondary horseradish peroxidase conjugated a $\mu$ nti-rabbit or anti-mouse antibodies (Thermo Fisher Scientific) and revealed using the Novex ${ }^{\mathrm{TM}}$ ECL Chemiluminescent Substrate Reagent kit (Invitrogen). For the reaction with the endogenous control, membranes were stripped with a stripping buffer (Thermo Fisher Scientific) and reprobed for GAPDH analysis. Bands were quantified by densitometry using the software ImageQuant TL (GE). 
Flow cytometry analysis

Both gastrocnemius were mechanically dissociated, and the product of dissociation was passed through $70 \mu \mathrm{m}$ and $40 \mu \mathrm{m}$ sieves respectively. The single cells obtained were counted and permeabilized utilizing ethanol 70\%. A total of $2 \times 10^{5}$ cells were analyzed for cell cycle assay using the Guava Cell Cycle Reagent for Flow Cytometry (Merck Millippore) protocol to verify the muscle cell cycle stage on a flow cytometer Aria (BD Biosciences).

\section{Histological analysis}

Hematoxylin-eosin (H\&E): Transverse cross sections of the right gastrocnemius were stained with $\mathrm{H} \& \mathrm{E}$ and histopathological evaluation was performed by measuring muscle fibers to obtain the fiber diameter utilizing ImageJ software $(n=100$ fibers/experimental group). The mean fiber diameter of each strain was obtained and the variation coefficient was calculated according with the formula: Standard Deviation x $1000 \div$ Diameter Mean (Victor Dubowitz, 2013). Results were represented as variation mean and variation coefficient. The stained sections were observed under a light microscope (Zeiss).

Picrossirius: To identify regions with collagen deposition, indicative of connective tissue replacement and infiltration between muscle fibers, the slides were immersed in Bouin fixative for twenty minutes and washed in water. The sections were stained with Sirius red $(0.2 \mathrm{~g})$ dissolved in saturated picric acid $(100 \mathrm{ml})$ for 60 minutes, dehydrated and mounted in Canada balsam. The differences were quantified by the positive area of staining, labeled in red, relative to the total area of the section, with the aid of ImageJ software (4-5 fields, $n=6$ animals/experimental group).

Immunofluorescence analysis for developmental myosin heavy chain (dMHC): The presence of dMHC indicates myogenic activity by newly differentiated fibers labeled in red. The $6 \mu \mathrm{m}$ muscle sections were double labeled with primary antibodies to dMHC (1:30; Vector; VP- M664) and laminin (1:50; Dako; Z0097), washed, and then incubated for $1 \mathrm{~h}$ with secondary antibodies Cy3-labeled sheep anti-mouse IgG (1:100; Sigma; C2181) and FITC-labeled donkey anti-rabbit IgG (1:100; Amersham; N1034), respectively. After washing, the slides were mounted with Vectashield+DAPI. Immunofluorescence micrographs were done on a fluorescence 
microscope (Zeiss) and the percentage of dMHC+/total fibers was quantified (4 fields, $n=6$ animals/experimental group). Fiber diameter of dMHC+ fibers of each strain was obtained and the variation coefficient was calculated according with the formula: Standard Deviation x $1000 \div$ Diameter Mean (Victor Dubowitz, 2013).

\section{Statistical analysis}

Differences between two groups were assessed using Mann-Whittney test. The statistical analyses were calculated using Minitab and a p-value of less than 0.05 was considered to be significant.

\section{Results}

Dystrophic muscle retains its satellite cells pool

The expression of the PAX7 transcription factor, which is correlated with the maintenance of satellite cells undifferentiated state, was analyzed in the 3 dystrophic models and compared to wild-type, and showed no statistically different expression in the mRNA level in dystrophic muscles. This important marker for self-renewal of satellite cells showed also a similar protein expression profile in the dystrophic strains, as compared to wild-type animals (Fig. 1).

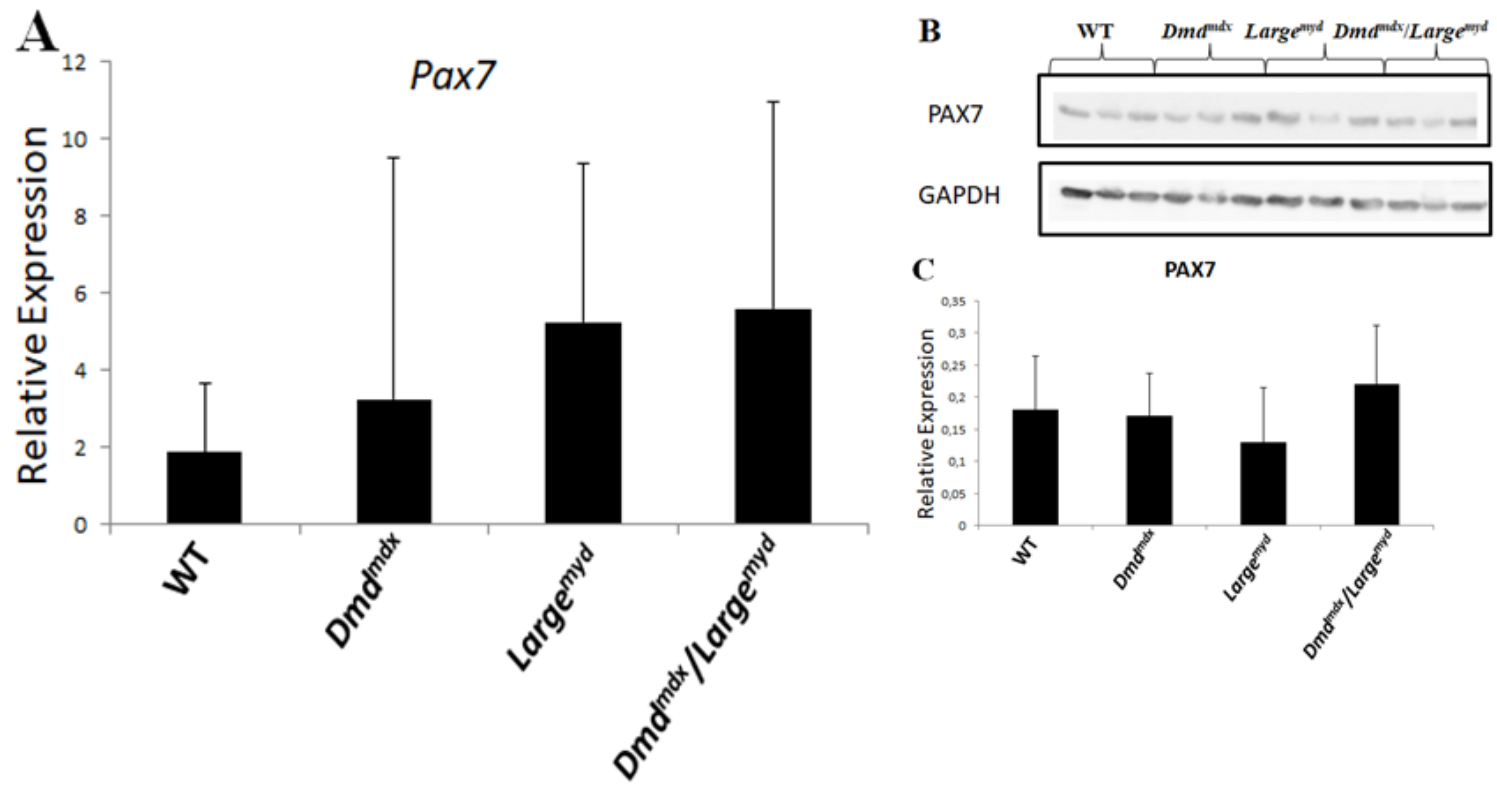

Figure 1: Expression analysis of PAX7 factor through (A) mRNA relative expression and (B) protein western blot analysis. No significant differences were found between WT and dystrophic strains using both approaches. (C) Densitometric quantification showed a similarity between the three strains and the wild-type animals. 
Dystrophic muscle single cells present a higher proportion of proliferating cells.

Analysis by flow cytometry of single cells from dissociated gastrocnemius muscles showed the proportions of cells in G2/M stage of: $10.76 \%$ in $D M D^{m d x}, 14.12 \%$ in Large $^{\text {myd }}$ and $6.54 \%$ in normal WT muscle (Fig 2). The increased proportion of these cells was statistically significant in the two dystrophic strains. In the synthesis fase (S), the proportions were of $3.32 \%, 3.92 \%$ and $5.32 \%$, in $\mathrm{WT}, D M D^{m d x}$ and Large $e^{m y d}$ respectively, but with no statistical differences in the two dystrophic models. This analysis was not possible to be performed in $D m d^{m d x} /$ Large $^{m y d}$ dystrophic model due to the lack of material.

\section{Cell Cycle}

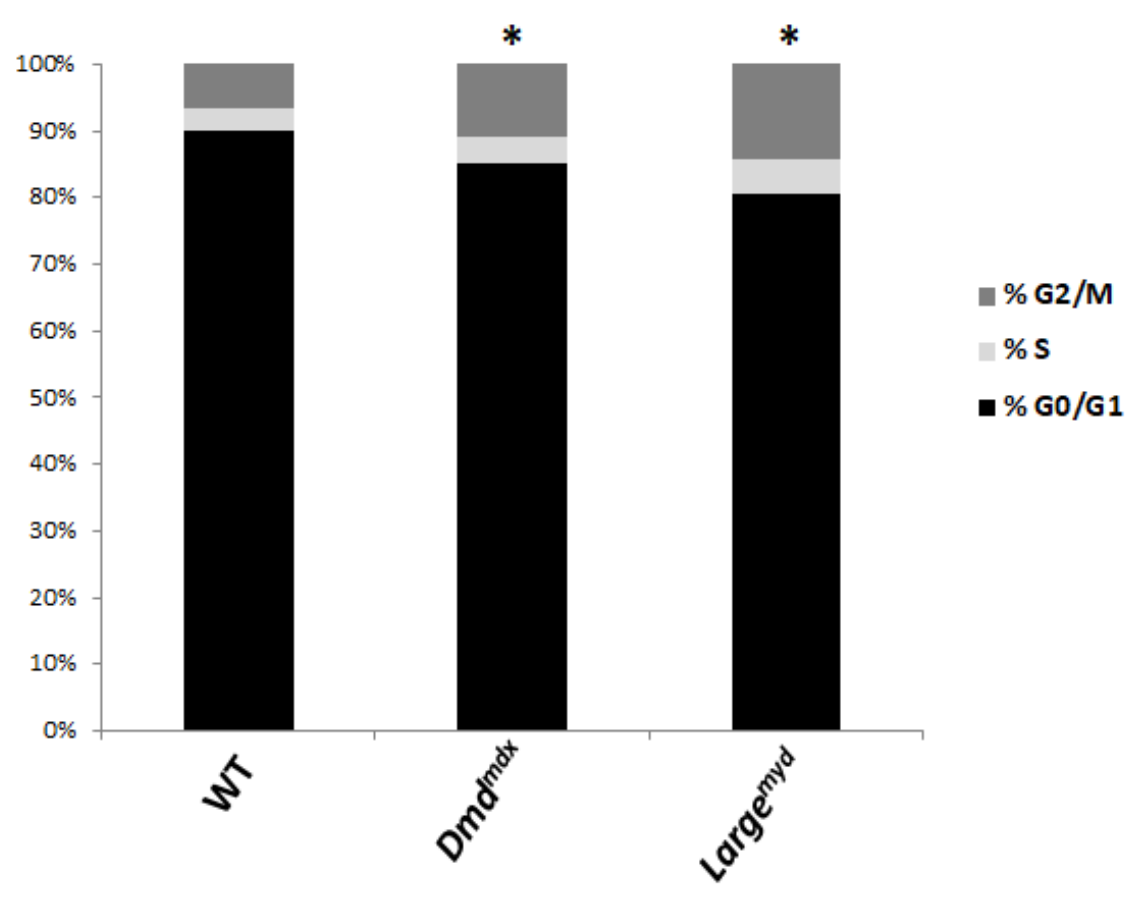

Figure 2: Distribution of muscle single cells according to cell cycle markers. Significant differences were found between control and the two dystrophic strains, in G2/M stage: *p < 0.05 .

Regeneration genes cascade is activated in the dystrophic muscle

We also investigated the relative expression of Myf5, Myod and Myogenin, which are important genes to satellite cells myogenic program. Our results showed that although similar expression was observed for Myf5 in all strains (Fig. 3A), a higher expression was observed for $M y o D$ in the $D M D^{m d x}$ strain (Fig. 3B). On the other hand, the expression of Myogenin was statistically elevated in the 3 dystrophic strains, as 
compared to the normal control (Fig. 3C). This high expression of Myogenin was confirmed through protein analysis as well (Fig. 3D and 3E).
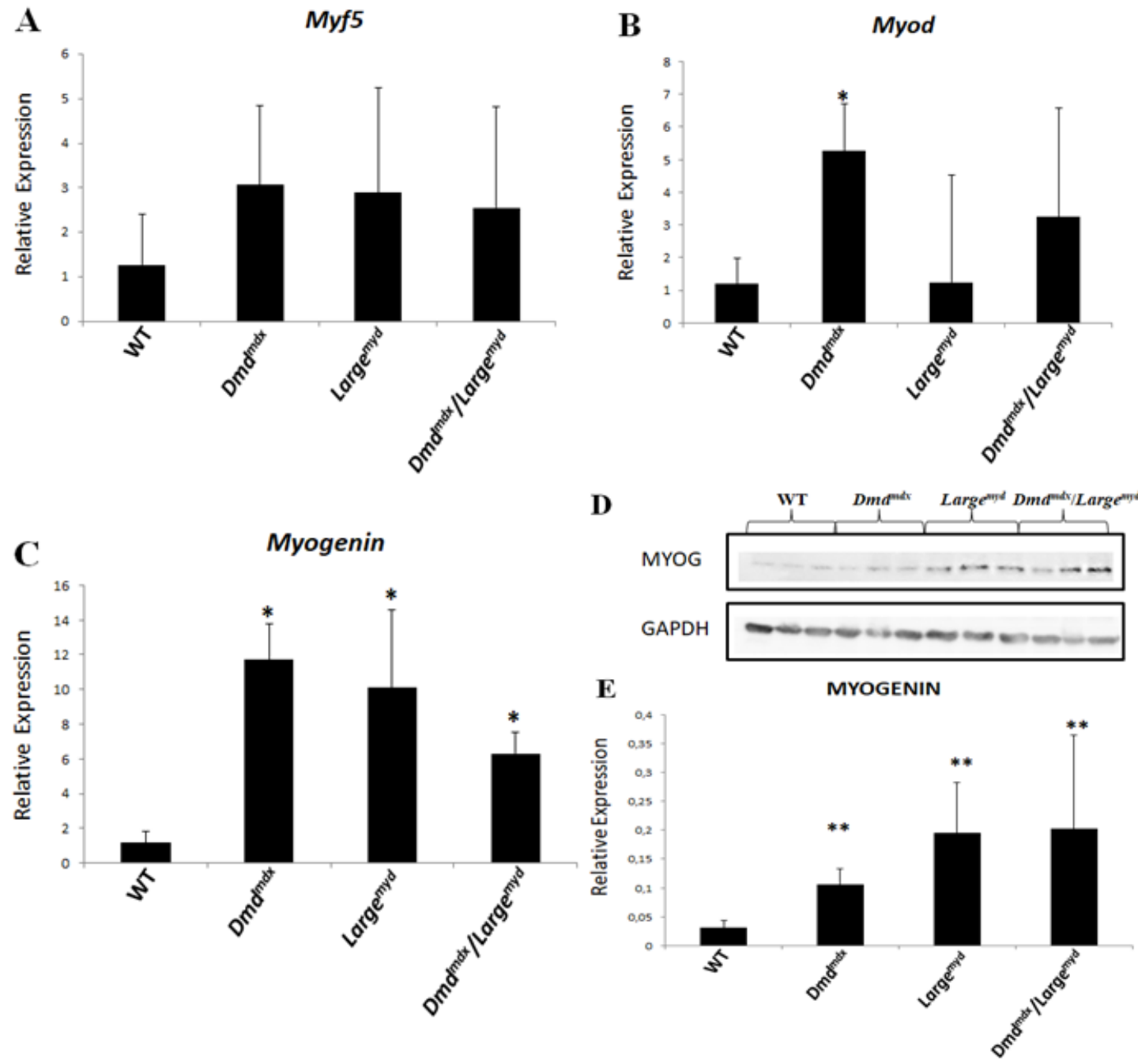

Figure 3: Relative expression of the genes involved in the myogenic program, in three dystrophic strains and in normal control (WT), (A) Myf5, (B) MyoD, (C) Myogenin. (D) MYOGENIN western blot protein analysis, (E) Densitometric analysis of myogenin protein results. Values are means \pm SD. Significant differences: ${ }^{*} p<0.05 ; * * p<0.01$.

\section{Dystrophic muscle retains the ability to form new fibers}

The number and diameter of new muscle fibers were evaluated using a marker of the developmental myosin isoform (Fig. 4A). Immunofluorescence analysis showed that the $D m d^{m d x}$ strain presented the greatest number of dMHC+ fibers (17\%), while the two more severe strains, Large $e^{m y d}$ and $D m d^{m d x} /$ Large $^{m y d}$ strains showed respectively $7 \%$ and $10 \%$ of new fibers (Fig. 4B). Interestingly, the diameter of these 
new fibers was also smaller in the dystrophic strains, with the mean of $33 \mu \mathrm{m}+/-$ $4.91 \mu \mathrm{m}$ in $D m d^{m d x}, 30 \mu \mathrm{m}+/-7.91 \mu \mathrm{m}$ in Large $^{m y d}$, and $20 \mu \mathrm{m}+/-3.05 \mu \mathrm{m}$ in $D m d^{m d x} /$ Large $^{m y d}$ (Fig. 4C), as compared to normal fiber size of $52 \mu \mathrm{m}+/-10 \mu \mathrm{m}$ (Fig. $\mathrm{HE}$ ). In addition, the size of these new fibers was more homogeneous, as shown by coefficient of variation analysis, which varied between 150 and 250 in the dystrophic strains, suggesting that these fibers remain small, not completing the regeneration process (Fig. 4D).

WT

A

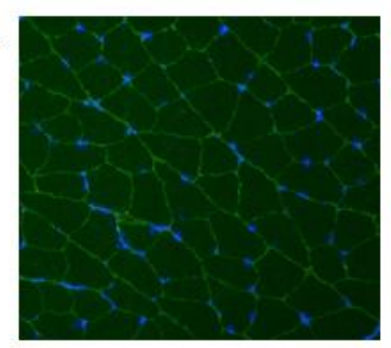

$D m d^{m d x}$

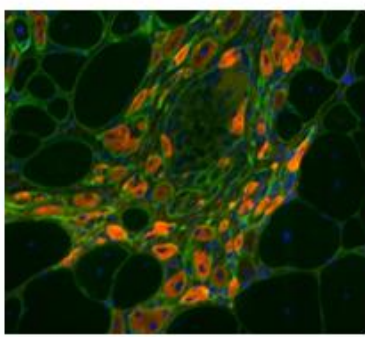

Large $^{\text {myd }}$

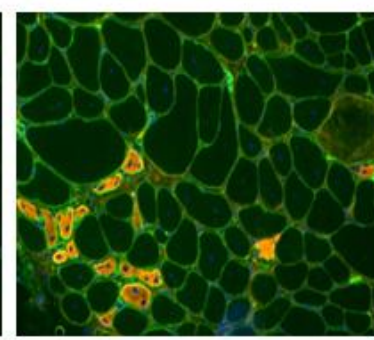

$\operatorname{Dmd}^{m d x} /$ Large $^{m y d}$

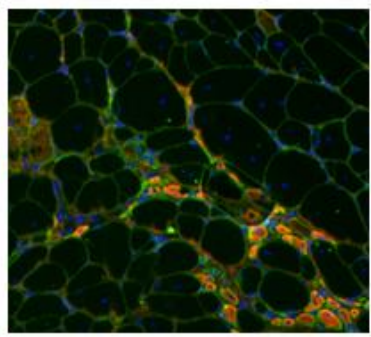

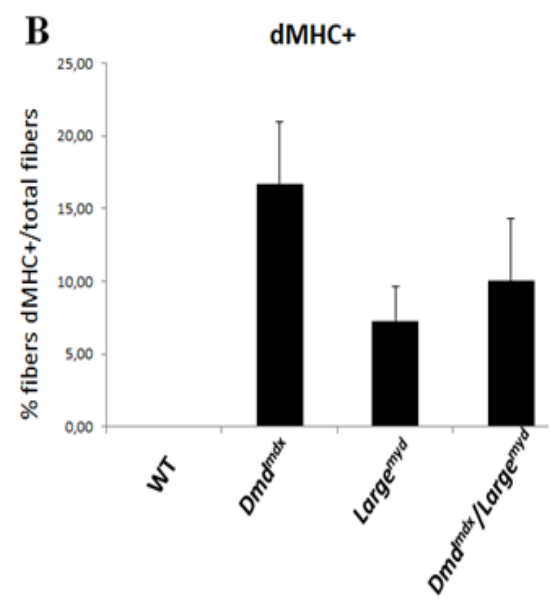
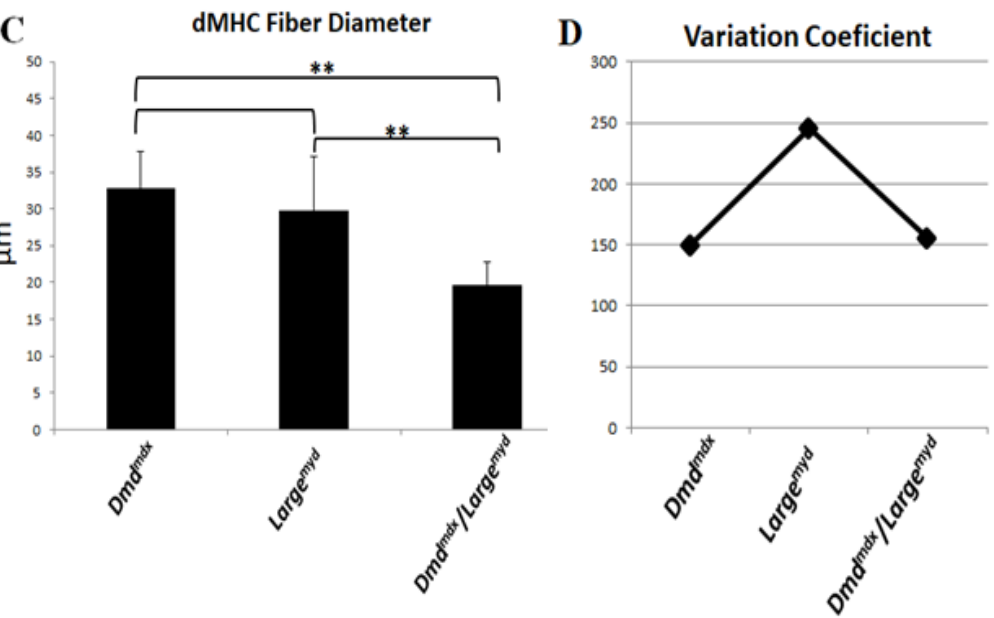

Figure 4: (A) Immunofluorescence staining for developmental isoform of myosin heavy chain (dMHC). dMHC+ fibers are labeled in red to identify newly formed myofibers, indicating regenerative response, magnification of 10X. (B) Quantitative analysis of percentage of fibers dMHC+/total fibers ( $\mathrm{n}=\sim 1500$ fibers/animal). (C) $\mathrm{dMHC}+$ fiber diameter $(\mathrm{n}=100)$. (D) Variation coefficient of $\mathrm{dMHC}+$ muscle fiber size. Values are means \pm SD. Significant differences: $* \mathrm{p}<0.05 ; * * p<0.01$.

\section{Muscle degeneration is intense in spite of regeneration}

The effect of regeneration in the degenerative process of muscles was evaluated through the quantification of connective tissue substitution, using picrosirius red 
staining (Fig. 5A). We observed more connective tissue infiltration in dystrophic mice than WT mice, and among the dystrophic strains, a higher proportion in the more severely affected muscles of the Large $e^{m y d}$ and $D m d^{m d x} / \operatorname{Larg}^{m y d}$ strains. (Fig. 5B).

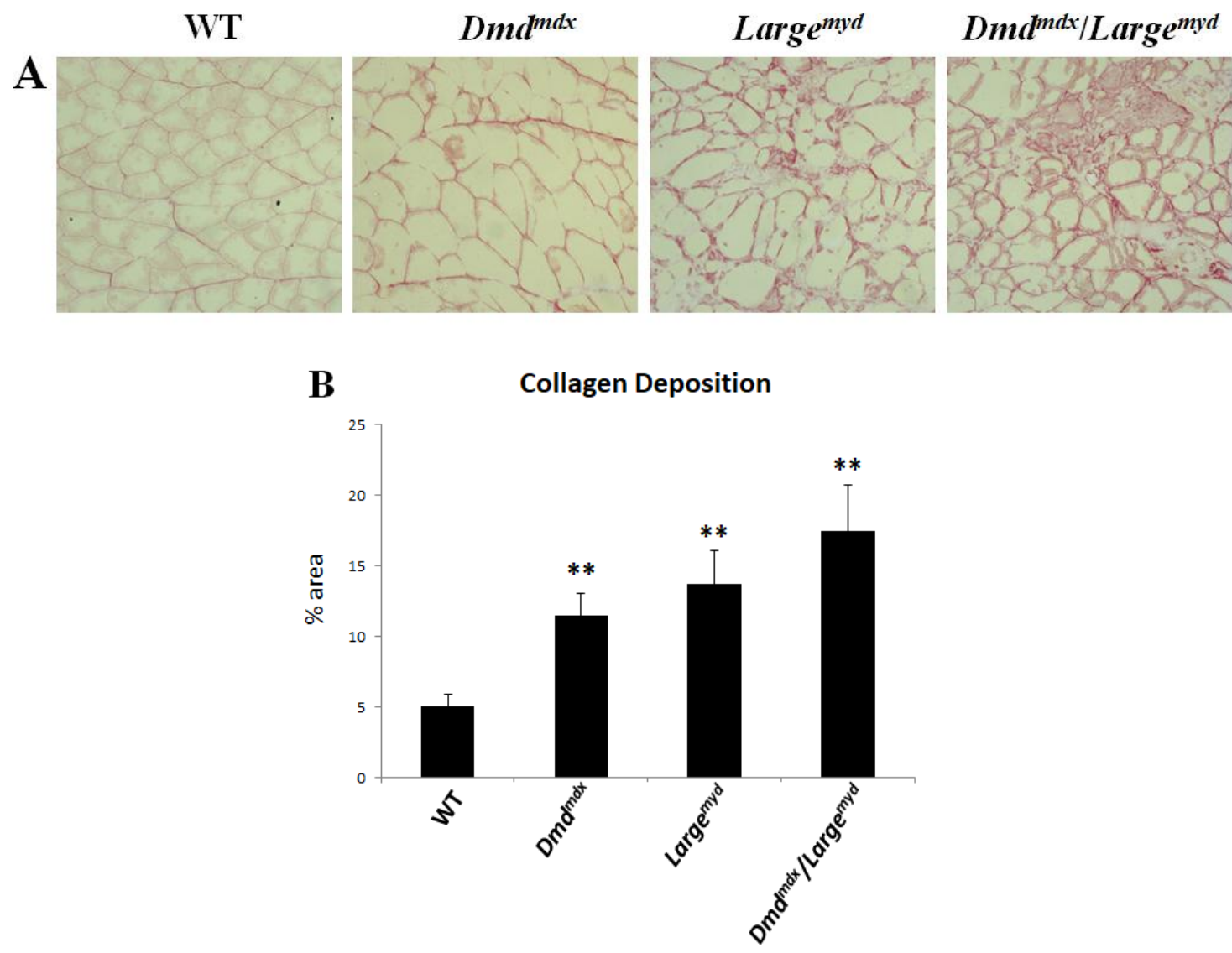

Figure 5: (A) Representative images of collagen deposition by Picrosirius red staining of gastrocnemius muscles of WT, Dmd $d^{m d x}$, Large $e^{\text {myd }}$ and Dmd $d^{m d x} /$ Large ${ }^{m y d}$ mice, magnification of 10X. (B) Quantification of percentage area of collagen deposition. Values are means \pm SD. Significant differences relative to WT muscle: ${ }^{*} \mathrm{p}<0.05$ and $* * \mathrm{p}<0.01$.

Variation in muscle fiber size is high in dystrophic muscles

Histological analysis of muscles through H\&E staining also showed a gradual increase in muscle degeneration and variation in fiber size (Fig. 6A and 6B). An increase in the variation coefficient of fiber size in dystrophic strains was observed, in accordance with the degree of muscle affection: $D m d^{m d x} /$ Large $e^{m y d}>$ Large $e^{m y d}>D m d^{m d x}$ (Fig. 6C). 

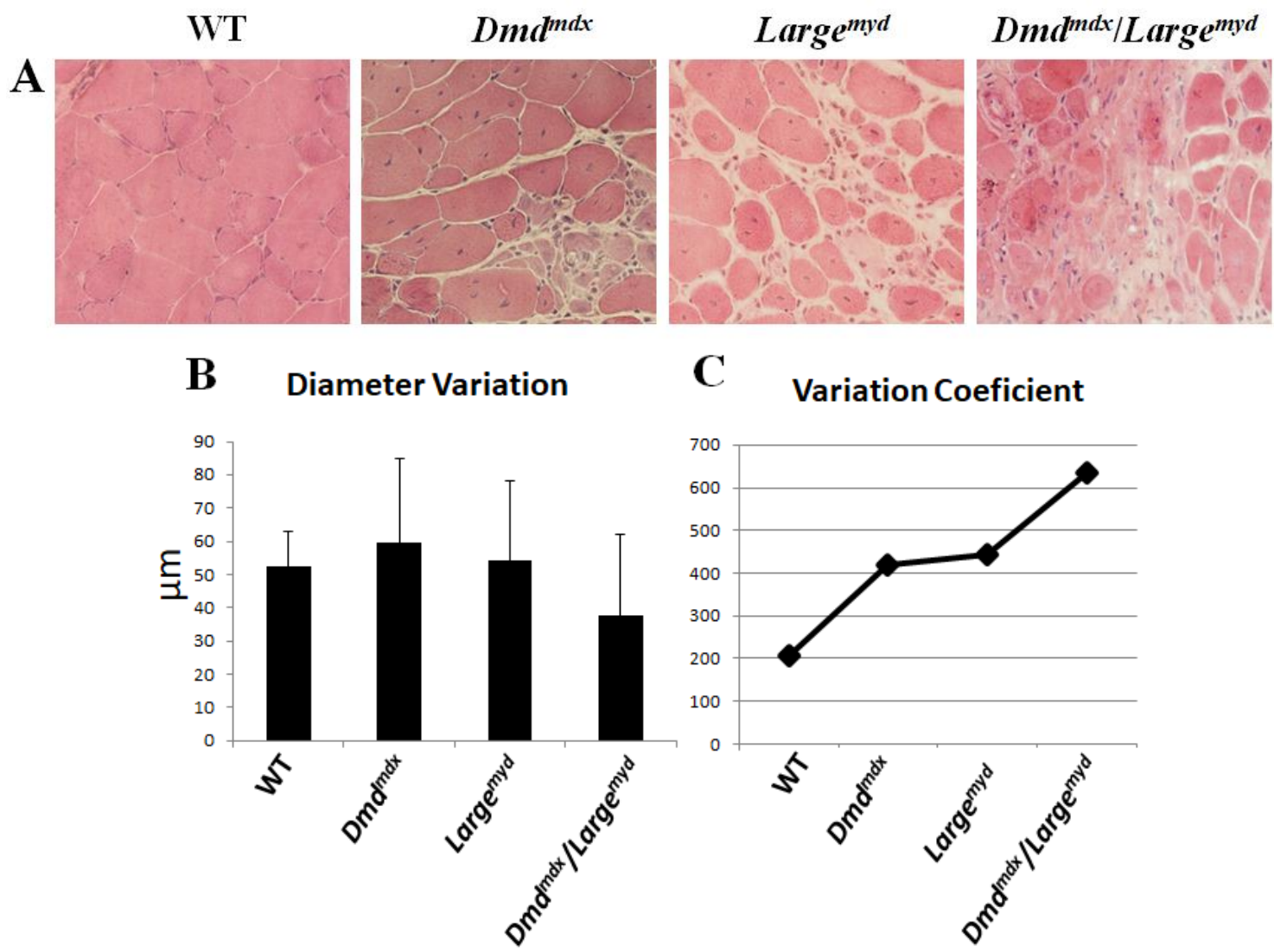

Figure 6: (A) Histopathological alterations in muscle using HE staining in 3 dystrophic strains and wild-type. (B) Muscle fibers mean diameter. (C) Variation coefficient of muscle fiber size ( $>250$ is considered pathogenic, Dubowitz et al, 2013).

\section{Discussion}

The reservoir of muscle precursor cells, the satellite cells (SCs), is responsible for after-birth growth and muscle regeneration as a response to injuries, either by exercise or disease. Since the first description in 1961 by (Mauro, 1961), SCs have been the target of a huge number of studies, aiming to understand their behavior, action and enviroment contribution. SCs are able to self-renew and replenish the stem cell pool, and their role is primordial in muscle regeneration. Upon injury, the regenerative response of the muscle includes SCs exit of quiescence and its activation, proliferation and fusion to form new myofibers. This process is accompanied by inflammation, with infiltration of immune cells, primarily macrophages. The dystrophic muscle is persistently injured, and the regenerative process is incessantly activated, recruiting SCs at higher rates than in normal tissue (Wakayama et al., 1979; Ishimoto et al., 1983; Matecki et al., 2004; Kottlors e Kirschner, 2010). Nevertheless, progressive replacement of muscle by fibrofatty tissue in dystrophic muscle impairs the regeneration 
process. Additionally, the SCs regenerative capacity is finite, and exhaustion of the pool of these cells has been considered a significant factor that contributes to progressive muscle deterioration in muscular dystrophies, as studied in Duchene Muscular Dystrophie (DMD) (Webster e Blau, 1990; Heslop et al., 2000). Therefore, the potential of stem cells to repair muscle is not sufficient to compensate the persistent degeneration process (Wallace e Mcnally, 2009).

On the other hand, several studies have shown an increase in the number of satelite cells in muscular dystrophies such as in DMD, (Wakayama et al., 1979; Matecki et al., 2004; Kottlors e Kirschner, 2010) as well as in myotonic dystrophies (Ishimoto et al., 1983).

The elucidation of players and mechanisms involved in SC function is of extreme importance, especially for therapeutic strategies. In this regard, many questions remain to be answered, such as how to deal with the heterogeneity and the choice between the ones with better capacity of self-renewal or the ones that could be more prone to differentiate. Quiescence and activation processes are also important aspects, since they can be regulated and used to direct activation of resident cells.

Here, we studied SC protein and gene expression in different forms of murine muscular dystrophies, with specific pattern of muscle histopathology, to correlate the impact of muscle degeneration in the population of SCs in these different environments.

\section{Dystrophic muscle retains its satellite cells pool}

The expression of the transcription factor PAX7 by SCs has been correlated with the maintenance of these cells in the undifferentiated state, being an important factor for self-renewal that can be expressed both by quiescent and by early activated SCs (Seale et al., 2004). The increase, maintenance or reduction of the pool of SCs in the dystrophic muscle is still controversial. Some previous studies have shown an increased number of satellite cells in dystrophic muscles as reported by (Ishimoto et al., 1983) in human myotonic dystrophies and (Kottlors e Kirschner, 2010) and (Wakayama et al., 1979) in DMD, with evidences also in the DMD mouse model Dmd ${ }^{m d x}$ (Matecki et al., 2004). On the other hand, other reports described fewer satellites cells in $D m d^{m d x}$ (Webster e Blau, 1990) and human DMD patients (Heslop et al., 2000). Our analysis of PAX7 expression, both through mRNA and protein quantification showed no statistical 
differences among the dystrophic strains as compared to normal control. The observation of normal expression of PAX7 in the murine dystrophic models suggests the maintenance of a normal pool of SCs despite the active process of regeneration and degeneration that occur in the $D m d^{m d x}$, Large $e^{m y d}$ and $D m d^{m d x} / \operatorname{Large}^{m y d}$.

Dystrophic muscle single cells present a higher proportion of proliferating cells.

The self-renewal capacity of SCs is extremely important for the replenishment of the stem cell pool, mainly in an active process of attempt to regenerate. The analysis of cell cycle markers in dissociated gastrocnemius muscle from the different mouse strains showed that dystrophic muscle resident single cells are in a higher proliferative state than non-dystrophic ones. A greater number of cells in the G2/M phase in dystrophic mice suggest an active cell division, contributing both to regeneration and to maintenance of the pool of SC in these muscles. In accordance with this data, although not statistically significant, more cells in the synthesis state ( $\mathrm{S}$ stage) were also observed in the two dystrophic strains. Therefore, this suggest that both the less affected $D m d^{m d x}$ as well as in the more severely affected Large ${ }^{\text {myd }}$ muscles are under an active cell division process. However, this population of muscle single cells is heterogeneous, and other than satellite cells can contribute with the pool of proliferating cells (Cooper et al., 2006; Tierney e Sacco, 2016).

\section{Regeneration genes cascade is activated in the dystrophic muscle}

The molecular players of regeneration are muscle regulatory factors, including MYF5 and MYOD, responsible for muscle-cell type determination and SCs activation, and MYOG, responsible for muscle differentiation. We thus investigate the relative expression of these genes in our three different dystrophic models.

At the mRNA level, we observed similar relative expression of the Myf5 factor in all four strains. Both activated and quiescent satellite cells express this factor, but quiescent cells can maintain their quiescence state using a post-transcriptional regulation by miR-31, which sequesters $M y f 5 \mathrm{mRNA}$ in messenger ribonucleoprotein (mRNP) granules. Upon activation, miR-31 levels decrease and Myf5 mRNA is released to translation (Van Rooij e Olson, 2007). Therefore, this could explain the similar relative quantification of mRNA in all strains.

On the other hand, the relative expression of $M y o D$ mRNA was significantly increased in the $D m d^{m d x}$ strain that shows the more significant pattern of muscle 
regeneration, which has been much studied in the past years (Dangain e Vrbova, 1984). MYOD can be expressed both by satellite cells, in first steps of satellite cells differentiation, and by myocytes in final steps of differentiation (Cooper et al., 1999; Bentzinger et al., 2012; Zammit, 2017). Upregulation of MYOD expression leads satellite cells to exit cell cycle and to differentiate and fuse, forming myotubes (Zammit, 2017). In fact, the muscle of this dystrophic model showed more regenerating fibers as observed by dMHC staining (Fig. 4), and this data confirms the high capacity of the satellite cells of the $D m d^{m d x}$ mouse to follow a myogenic program, and, despite the dystrophic characteristics, to be able to form new fibers (Boldrin et al., 2015).

In the terminal step of myogenesis, the expression of Myogenin has a key role in the process of differentiation of SCs to myotubes. High expression of Myogenin initiates myoblast maturation to myocytes, myocytes fusion and myotube formation, a process extremely active in dystrophic muscle (Rudnicki et al., 2008; Zammit, 2017). We studied Myogenin expression in the dystrophic strains to investigate whether myotube formation is impaired in these models. Gene expression analysis showed a significantly increase of Myogenin expression as well as protein expression in the three dystrophic strains, suggesting the occurrence of appropriate myoblast maturation to myocytes, fusion induction, and myotube formation in all the dystrophic processes (Venuti et al., 1995; Rudnicki et al., 2008; Zammit, 2017).

\section{Dystrophic muscle retains the ability to form new fibers}

Newly regenerated muscle fibers have particular characteristics such as central myonuclei, basophilic pattern on H\&E staining, and expression of an isoform of developmental myosin heavy chain (dMHC) (Heslop et al., 2000; Victor Dubowitz, 2013). In our analysis of regenerating fibers expressing dMHC, we observed a significant number of new fibers in all the dystrophic strains, including the most severely affected double mutant $D m d^{m d x} / \operatorname{Large}^{m y d}$. This suggest that the three dystrophic models retain the regenerative capacity, including the maintenance of SCs pool, the proliferation capacity, late differentiation marker (Myogenin) expression, and finally, formation of new fibers. The $D m d^{m d x}$ strain showed the higher number of regenerating fibers, which are compatible with its great regenerative capacity and milder dystrophic phenotype. The Large $e^{m y d}$ and $D m d^{m d x} /$ Large $e^{m y d}$ strains, on the other hand, although both show a more severe dystrophic phenotype, also presented a 
significant amount of regenerating fibers in their muscle, suggesting that the formation of new fibers is possible even when the muscle is already significantly degenerated (Wallace e Mcnally, 2009).

However, when measuring the diameter of these newly formed $\mathrm{dMHC}+$ fibers, we observed that on average, all dystrophic strains showed thinner regenerating fibers, with the double mutant presenting the thinnest $\mathrm{dMHC}+$ muscle fibers as compared to other strains (Fig. 4C). In addition, fiber size variation coefficient analysis (Victor Dubowitz, 2013) showed small variation, which suggests the maintenance of these regenerating fibers in an immature small diameter state, not evolving to a normal fiber size. Taken together, these results suggest possible incomplete fiber maturation characteristics, which could be determinant of the dysfunction of these fibers.

\section{Muscle degeneration is intense in spite of the regeneration}

We then studied the histopathological degree of muscle degeneration, both through connective tissue replacement and variation in fiber size, in the three dystrophic strains, to correlate with the capacity of regeneration. A coefficient variation of muscle fiber size > 250 is considered as pathogenic in the dystrophic muscle (Victor Dubowitz, 2013). We observed more connective tissue infiltration in dystrophic mice than in WT mice. In the dystrophic strains with more muscle weakness such as $\operatorname{Large}^{\text {myd }}$ and $D m d^{m d x} /$ Large $e^{m y d}$, we observed increased collagen deposition, being the double mutant $D m d^{m d x} /$ Large $e^{m y d}$ more affected than the others. We then conclude that the activated regeneration in the dystrophic muscle is not an indicative of effective improvement of dystrophic characteristics, but an incomplete tentative to restore the muscle fibers.

\section{Conclusion}

In conclusion, our findings suggest that dystrophic muscles, independently of the degree of degeneration, retain the pool of satellite cells with proliferating capacity and ready to respond to regenerating stimuli. The potential to repair is preserved by the upregulation of myogenic factors like Myogenin and by the formation of new fibers expressing $\mathrm{dMHC}$ isoform. On the other hand, the maturation of these new fibers is incomplete, since these fibers remain small, and do not prevent the degeneration of the muscle, as observed by the intense substitution by connective tissue. 


\section{References}

BENTZINGER, C. F.; WANG, Y. X.; RUDNICKI, M. A. Building muscle: molecular regulation of myogenesis. Cold Spring Harb Perspect Biol, v. 4, n. 2, Feb 2012. ISSN 1943-0264.

BOLDRIN, L.; ZAMMIT, P. S.; MORGAN, J. E. Satellite cells from dystrophic muscle retain regenerative capacity. Stem Cell Res, v. 14, n. 1, p. 20-9, Jan 2015. ISSN 18767753.

BROCKINGTON, M. et al. Localization and functional analysis of the LARGE family of glycosyltransferases: significance for muscular dystrophy. Hum Mol Genet, v. 14, n. 5, p. 657-65, Mar 2005. ISSN 0964-6906.

CHARGÉ, S. B.; RUDNICKI, M. A. Cellular and molecular regulation of muscle regeneration. Physiol Rev, v. 84, n. 1, p. 209-38, Jan 2004. ISSN 0031-9333.

COOPER, R. N.; BUTLER-BROWNE, G. S.; MOULY, V. Human muscle stem cells. Curr Opin Pharmacol, v. 6, n. 3, p. 295-300, Jun 2006. ISSN 1471-4892.

COOPER, R. N. et al. In vivo satellite cell activation via Myf5 and MyoD in regenerating mouse skeletal muscle. J Cell Sci, v. 112 ( Pt 17), p. 2895-901, Sep 1999. ISSN 0021-9533.

DANGAIN, J.; VRBOVA, G. Muscle development in mdx mutant mice. Muscle Nerve, v. 7, n. 9, p. 700-4, 1984 Nov-Dec 1984. ISSN 0148-639X.

GREWAL, P. K.; HEWITT, J. E. Mutation of Large, which encodes a putative glycosyltransferase, in an animal model of muscular dystrophy. Biochim Biophys Acta, v. 1573, n. 3, p. 216-24, Dec 2002. ISSN 0006-3002.

HESLOP, L.; MORGAN, J. E.; PARTRIDGE, T. A. Evidence for a myogenic stem cell that is exhausted in dystrophic muscle. J Cell Sci, v. 113 ( Pt 12), p. 2299-308, Jun 2000. ISSN 0021-9533.

HOFFMAN, E. P.; BROWN, R. H.; KUNKEL, L. M. Dystrophin: the protein product of the Duchenne muscular dystrophy locus. Cell, v. 51, n. 6, p. 919-28, Dec 1987. ISSN 0092-8674.

ISHIMOTO, S. et al. A quantitative study of the muscle satellite cells in various neuromuscular disorders. J Neurol Sci, v. 62, n. 1-3, p. 303-14, Dec 1983. ISSN 0022$510 X$.

KOTTLORS, M.; KIRSCHNER, J. Elevated satellite cell number in Duchenne muscular dystrophy. Cell Tissue Res, v. 340, n. 3, p. 541-8, Jun 2010. ISSN 1432-0878.

MARTINS, P. C. et al. Dmdmdx/Largemyd: a new mouse model of neuromuscular diseases useful for studying physiopathological mechanisms and testing therapies. Dis Model Mech, v. 6, n. 5, p. 1167-74, Sep 2013. ISSN 1754-8411. 
MATECKI, S.; GUIBINGA, G. H.; PETROF, B. J. Regenerative capacity of the dystrophic (mdx) diaphragm after induced injury. Am J Physiol Regul Integr Comp Physiol, v. 287, n. 4, p. R961-8, Oct 2004. ISSN 0363-6119.

MAURO, A. Satellite cell of skeletal muscle fibers. J Biophys Biochem Cytol, v. 9, p. 493-5, Feb 1961. ISSN 0095-9901.

RUDNICKI, M. A. et al. The molecular regulation of muscle stem cell function. Cold Spring Harb Symp Quant Biol, v. 73, p. 323-31, 2008. ISSN 1943-4456.

SEALE, P. et al. Pax7 is necessary and sufficient for the myogenic specification of CD45+:Sca1+ stem cells from injured muscle. PLoS Biol, v. 2, n. 5, p. E130, May 2004. ISSN 1545-7885.

SICINSKI, P. et al. The molecular basis of muscular dystrophy in the mdx mouse: a point mutation. Science, v. 244, n. 4912, p. 1578-80, Jun 1989. ISSN 0036-8075.

SUNADA, Y.; CAMPBELL, K. P. Dystrophin-glycoprotein complex: molecular organization and critical roles in skeletal muscle. Curr Opin Neurol, v. 8, n. 5, p. 37984, Oct 1995. ISSN 1350-7540.

TIERNEY, M. T.; SACCO, A. Satellite Cell Heterogeneity in Skeletal Muscle Homeostasis. Trends Cell Biol, v. 26, n. 6, p. 434-44, Jun 2016. ISSN 1879-3088.

TOWNSEND, D. Finding the sweet spot: assembly and glycosylation of the dystrophinassociated glycoprotein complex. Anat Rec (Hoboken), v. 297, n. 9, p. 1694-705, Sep 2014. ISSN 1932-8494.

VAINZOF, M. et al. Animal models for genetic neuromuscular diseases. J Mol Neurosci, v. 34, n. 3, p. 241-8, Mar 2008. ISSN 0895-8696.

VAN ROOIJ, E.; OLSON, E. N. MicroRNAs: powerful new regulators of heart disease and provocative therapeutic targets. J Clin Invest, v. 117, n. 9, p. 2369-76, Sep 2007. ISSN 0021-9738.

VENUTI, J. M. et al. Myogenin is required for late but not early aspects of myogenesis during mouse development. J Cell Biol, v. 128, n. 4, p. 563-76, Feb 1995. ISSN 00219525 .

VICTOR DUBOWITZ, C. S. A. A. O. Muscle Biopsy: A Practical Approach. $4^{\mathrm{a}}$. England: Elsevier, 2013. 592.

WAKAYAMA, Y. et al. Quantitative ultrastructural study of muscle satellite cells in Duchenne dystrophy. Neurology, v. 29, n. 3, p. 401-7, Mar 1979. ISSN 0028-3878.

WALLACE, G. Q.; MCNALLY, E. M. Mechanisms of muscle degeneration, regeneration, and repair in the muscular dystrophies. Annu Rev Physiol, v. 71, p. 3757, 2009. ISSN 1545-1585.

WEBSTER, C.; BLAU, H. M. Accelerated age-related decline in replicative life-span of Duchenne muscular dystrophy myoblasts: implications for cell and gene therapy. Somat Cell Mol Genet, v. 16, n. 6, p. 557-65, Nov 1990. ISSN 0740-7750. 
YOSHIDA, M.; OZAWA, E. Glycoprotein complex anchoring dystrophin to sarcolemma. J Biochem, v. 108, n. 5, p. 748-52, Nov 1990. ISSN 0021-924X.

ZAMMIT, P. S. Function of the myogenic regulatory factors Myf5, MyoD, Myogenin and MRF4 in skeletal muscle, satellite cells and regenerative myogenesis. Semin Cell Dev Biol, v. 72, p. 19-32, Dec 2017. ISSN 1096-3634. 


\section{Capítulo 4 - Discussão}

Desde sua primeira descrição por Mauro (1961) as SCs têm sido alvo de inúmeros estudos com o objetivo de entender seu comportamento, suas ações e suas contribuições para seu microambiente. Algumas características e funções das SCs já são bem conhecidas, como a contribuição para o desenvolvimento muscular logo após o nascimento, bem como sua participação na regeneração muscular causada por lesões. Após lesão muscular, seja ela ocasionada por doença ou por atividade física cotidiana, essas células são ativadas e contribuem diretamente para a regeneração muscular. Quando ativadas, estas células podem também contribuir para a manutenção do pool de células-tronco no músculo, assim mantendo a população de células-tronco musculares.

No músculo distrófico, devido ao processo constante de lesão muscular, as SCs são constantemente recrutadas e em taxas mais altas do que no músculo normal. Apesar do maior recrutamento e ativação das SCs, existe uma substituição progressiva de fibras musculares degeneradas por tecido conjuntivo e adiposo, o que prejudica o processo regenerativo. Além disso, segundo alguns estudos, as SCs têm capacidade limitada de contribuir para o processo de regeneração em pacientes com DMD. Sendo assim, a contribuição das SCs para a regeneração do músculo distrófico não é suficiente. Por outro lado, alguns estudos mostram um aumento na quantidade de SCs em quadro de distrofia muscular (Wakayama et al., 1979; Ishimoto et al., 1983; Matecki et al., 2004; Kottlors e Kirschner, 2010).

A elucidação dos mecanismos envolvidos na atuação das SCs é de extrema importância, especialmente para estratégias terapêuticas. Muitas questões precisam ser respondidas, por exemplo, como lidar com a heterogeneidade entre populações de SCs para uso em uma possível terapia gênica. Os processos de ativação e manutenção da quiescência também são aspectos importantes, uma vez que podem ser regulados e utilizados para direcionar a ativação das SCs.

Neste projeto, estudamos a expressão gênica e de proteínas, bem como características do músculo distrófico em diferentes modelos murinos para distrofia muscular. Cada modelo possui um padrão histopatológico específico, e nosso objetivo foi correlacionar o impacto da degeneração muscular, particular em cada modelo, na população de SCs nestes diferentes ambientes. 


\section{O pool de SCs é mantido no músculo distrófico}

Em nossa análise da expressão de PAX7, tanto por meio da quantificação de mRNA como de proteínas, não verificamos diferenças estatísticas entre as linhagens distróficas em comparação com o controle normal. A expressão de PAX7 está relacionada com a manutenção do pool de SCs no estado indiferenciado, sendo um fator importante para a autorrenovação e pode ser expresso tanto por SCs quiescentes quanto por recém-ativadas. $\mathrm{O}$ aumento, manutenção ou redução do pool de SCs no músculo distrófico ainda é controverso. Alguns estudos anteriores mostraram um aumento do número de células satélite em músculos distróficos, conforme relatado em distrofias miotônicas humanas e DMD (Wakayama et al., 1979; Ishimoto et al., 1983; Kottlors e Kirschner, 2010) e no camundongo $D m d^{m d x}$ (Matecki et al., 2004). Por outro lado, outros trabalhos descreveram menos células satélite em camundongos $D m d^{m d x}$ (Webster e Blau, 1990) e pacientes com DMD humana (Heslop et al., 2000). A observação da expressão normal de PAX7 nos modelos distróficos murinos sugere a manutenção normal do pool de SCs, apesar do processo ativo de regeneração e degeneração que ocorre nos camundongos $D m d^{m d x}, \operatorname{Large}^{m y d}$ e $D m d^{m d x} / \operatorname{Large}^{m y d}$.

\section{O músculo distrófico apresenta maior proporção de células em estado proliferativo}

A capacidade de autorrenovação das SCs é extremamente importante para a manutenção do pool, principalmente em um ambiente que exige um processo de regeneração adequado. Foi realizada uma análise do estado proliferativo das células musculares isoladas de camundongos distróficos e normais, utilizando marcadores de ciclo celular. Nossa análise mostrou maior quantidade de células em estágio de proliferação G2/M em músculos de camundongos distróficos, o que sugere uma divisão celular ativa, e uma possível contribuição para o processo de regeneração e manutenção do pool de SCs. Células em estágio de síntese de DNA (fase S) também foram observadas em maior número nos músculos distróficos, embora a diferença não seja estatisticamente significativa. Estes dados sugerem que o músculo dos camundongos $D m d^{m d x}$ e Large $e^{m y d}$ estão sob um processo de divisão celular ativa, ressaltando que a 
população de células únicas no músculo é heterogênea e, portanto, outras células que não as SCs também podem estar sendo analisadas.

\section{A cascata de regeneração está ativada no músculo distrófico}

Para uma análise mais detalhada da regulação do estado de ativação e diferenciação das SCs, fatores de regulação miogênica, incluindo MYF5 e MYOD, responsáveis pela determinação do tipo celular e pela ativação das SCs, e Miogenina, responsável pela diferenciação e fusão de miócitos, foram estudados. No nível de mRNA, observamos uma expressão relativa semelhante do fator Myf5 nas quatro linhagens, e o mRNA Myf5 apresenta uma particularidade. Tanto as SCs ativadas quanto quiescentes expressam esse fator, mas as células quiescentes podem manter seu estado de quiescência usando uma regulação pós-transcricional através do miR-31. Os miR-31 sequestram o mRNA Myf5 em grânulos de ribonucleoproteína mensageira (mRNP). Após a ativação das SCs, os níveis de miR-31 diminuem e o mRNA Myf5 é liberado para tradução (Van Rooij e Olson, 2007). Portanto, isso poderia explicar a quantificação relativa similar do mRNA em todas as linhagens. Por outro lado, a expressão relativa de Myod estava significantemente aumentada na linhagem $D m d^{m d x}$, que mostra um padrão de regeneração muscular ativo (Dangain e Vrbova, 1984). MYOD pode ser expresso tanto pelas SCs recém-ativadas, quanto por miócitos em etapas finais de diferenciação (Cooper et al., 1999; Bentzinger et al., 2012; Zammit, 2017). A regulação ascendente da expressão de MYOD leva as SCs à saída do ciclo celular, à diferenciação e fusão, formando miotubos (Zammit, 2017). De fato, o músculo deste modelo distrófico mostrou mais fibras regeneradas como observado pela coloração com dMHC, e esses dados confirmam a alta capacidade das SCs do camundongo $D m d^{m d x}$ de seguir um programa miogênico e, apesar das características distróficas, formarem novas fibras (Boldrin et al., 2015).

$\mathrm{Na}$ fase final da miogênese, a expressão de Miogenina tem um papel fundamental no processo de diferenciação de SCs em miotubos. A alta expressão de Miogenina inicia a maturação de mioblastos em miócitos, fusão de miócitos e formação de miotubos, um processo extremamente ativo no músculo distrófico (Rudnicki et al., 2008, Zammit, 2017). Estudamos a expressão de Miogenina nas três linhagens distróficas para investigar se a formação de miotubos está prejudicada nesses modelos. 
A análise da expressão de genes, bem como da expressão da proteína, mostrou um aumento significativo da expressão da Miogenina nas três linhagens distróficas. Estes dados sugerem a ocorrência de maturação adequada de mioblastos para miocitos, indução de fusão e formação de miotubos em todos os processos distróficos analisados (Venuti et al., 1995; Rudnicki et al., 2008; Zammit, 2017).

\section{O músculo distrófico mantém a capacidade de formar novas fibras}

As fibras musculares recém-regeneradas possuem características particulares, como mionúcleos centrais, o padrão basofílico na coloração $H \& E$ e a expressão da isoforma da miosina de cadeia pesada desenvolvimento (dMHC) (Heslop et al., 2000; Victor Dubowitz, 2013). Em nossa análise de fibras regenerando que expressam dMHC, observamos um número significativo de novas fibras em todas as linhagens distróficas, incluindo o mais gravemente afetado $\mathrm{Dmd}^{m d x} / \operatorname{Large}^{m y d}$. Isso sugere que os três modelos distróficos mantêm a capacidade regenerativa, incluindo a manutenção do pool de SCs, a capacidade de proliferação, a expressão do marcador de diferenciação tardia (Myogenin) e, finalmente, a formação de novas fibras. A linhagem $D m d^{m d x}$ mostrou maior número de fibras regeneradas, que são compatíveis com sua grande capacidade regenerativa e fenótipo distrófico mais leve. Por outro lado, as linhagens Large $^{\text {myd }}$ e $D m d^{m d x} /$ Large $e^{m y d}$, embora ambas mostrem um fenótipo distrófico mais grave, também apresentaram uma quantidade significativa de fibras regenerando em seus músculos, sugerindo que a formação de novas fibras é possível mesmo quando o músculo já é significativamente degenerado (Wallace e Mcnally, 2009).

No entanto, medindo o diâmetro dessas fibras dMHC+ recém-formadas, observamos que, em média, todas as linhagens distróficas apresentaram fibras em regeneração mais finas, com o duplo mutante apresentando as mais finas fibras musculares dMHC+ em comparação com outras linhagens distróficas. Além disso, a análise do coeficiente de variação do tamanho da fibra (Victor Dubowitz, 2013) mostrou pequena variação, o que sugere a manutenção dessas fibras em regeneração em um estado imaturo, com diâmetro pequeno, não evoluindo para um tamanho normal de fibra. Em conjunto, esses resultados sugerem possíveis características incompletas de maturação de fibras, que podem ser determinantes da disfunção destas. 


\section{A degeneração muscular é intensa apesar da regeneração}

Nós estudamos o grau histopatológico de degeneração muscular tanto pela substituição do tecido conjuntivo quanto pela variação no tamanho da fibra nas três linhagens distróficas, para correlacionar com a capacidade de regeneração. Uma variação do coeficiente de tamanho da fibra muscular > 250 é considerada como patogênica no músculo distrófico (Victor Dubowitz, 2013), e foi constatada em todos os modelos estudados. Observamos mais infiltração de tecido conjuntivo em camundongos distróficos do que em camundongos WT. Nas linhagens distróficas com maior fraqueza muscular, como Large $e^{m y d}$ e $D m d^{m d x} / \operatorname{Large}^{\text {myd }}$, observamos aumento da deposição de colágeno, sendo o duplo mutante $D m d^{m d x} /$ Large ${ }^{\text {myd }}$ mais afetado do que os outros. Nós concluímos que a regeneração ativada no músculo distrófico não é indicativa de melhora efetiva das características distróficas, mas uma tentativa incompleta para restaurar as fibras musculares.

\section{Conclusão}

Em conclusão, nossos achados sugerem que os músculos distróficos, independentemente do grau de degeneração, mantêm o pool de células satélite com capacidade de proliferação e estão prontos para responder aos estímulos regeneradores. O potencial de reparação é preservado pela regulação positiva de fatores miogênicos como Miogenina e pela formação de novas fibras que expressam a isoforma dMHC. Por outro lado, a maturação destas novas fibras é incompleta, uma vez que estas fibras permanecem pequenas e não impedem a degeneração do músculo, como observado pela substituição intensa de fibras musculares por tecido conjuntivo. 


\section{Referências}

ABMAYR, S. M.; PAVLATH, G. K. Myoblast fusion: lessons from flies and mice. Development, v. 139, n. 4, p. 641-56, Feb 2012. ISSN 1477-9129.

ALMEIDA, C. F. et al. Muscle Satellite Cells: Exploring the Basic Biology to Rule Them. Stem Cells Int, v. 2016, p. 1078686, 2016. ISSN 1687-966X.

ARANDA, P. S.; LAJOIE, D. M.; JORCYK, C. L. Bleach gel: a simple agarose gel for analyzing RNA quality. Electrophoresis, v. 33, n. 2, p. 366-9, Jan 2012. ISSN 15222683.

BENTZINGER, C. F.; WANG, Y. X.; RUDNICKI, M. A. Building muscle: molecular regulation of myogenesis. Cold Spring Harb Perspect Biol, v. 4, n. 2, Feb 2012. ISSN 1943-0264.

BISCHOFF, R.; HEINTZ, C. Enhancement of skeletal muscle regeneration. Dev Dyn, v. 201, n. 1, p. 41-54, Sep 1994. ISSN 1058-8388.

BOLDRIN, L.; ZAMMIT, P. S.; MORGAN, J. E. Satellite cells from dystrophic muscle retain regenerative capacity. Stem Cell Res, v. 14, n. 1, p. 20-9, Jan 2015. ISSN 18767753.

BRAUN, T. et al. Targeted inactivation of the muscle regulatory gene Myf-5 results in abnormal rib development and perinatal death. Cell, v. 71, n. 3, p. 369-82, Oct 1992. ISSN 0092-8674.

BROCKINGTON, M. et al. Localization and functional analysis of the LARGE family of glycosyltransferases: significance for muscular dystrophy. Hum Mol Genet, v. 14, n. 5, p. 657-65, Mar 2005. ISSN 0964-6906.

BROWNING, C. A. et al. A rapid PCR method for genotyping the Large(myd) mouse, a model of glycosylation-deficient congenital muscular dystrophy. Neuromuscul Disord, v. 15, n. 5, p. 331-5, May 2005. ISSN 0960-8966.

BULFIELD, G. et al. X chromosome-linked muscular dystrophy (mdx) in the mouse. Proc Natl Acad Sci U S A, v. 81, n. 4, p. 1189-92, Feb 1984. ISSN 0027-8424 (Print).

CHARGE, S. B.; RUDNICKI, M. A. Cellular and molecular regulation of muscle regeneration. Physiol Rev, v. 84, n. 1, p. 209-38, Jan 2004. ISSN 0031-9333 (Print).

CHARGÉ, S. B.; RUDNICKI, M. A. Cellular and molecular regulation of muscle regeneration. Physiol Rev, v. 84, n. 1, p. 209-38, Jan 2004. ISSN 0031-9333.

CHEN, J. C.; GOLDHAMER, D. J. Skeletal muscle stem cells. Reprod Biol Endocrinol, v. 1, p. 101, Nov 13 2003. ISSN 1477-7827 (Electronic).

CHUNG, J. et al. Twenty-year follow-up of newborn screening for patients with muscular dystrophy. Muscle Nerve, Aug 2015. ISSN 1097-4598. 
COOPER, R. N.; BUTLER-BROWNE, G. S.; MOULY, V. Human muscle stem cells. Curr Opin Pharmacol, v. 6, n. 3, p. 295-300, Jun 2006. ISSN 1471-4892.

COOPER, R. N. et al. In vivo satellite cell activation via Myf5 and MyoD in regenerating mouse skeletal muscle. J Cell Sci, v. 112 ( Pt 17), p. 2895-901, Sep 1999. ISSN 0021-9533.

DANGAIN, J.; VRBOVA, G. Muscle development in mdx mutant mice. Muscle Nerve, v. 7, n. 9, p. 700-4, 1984 Nov-Dec 1984. ISSN 0148-639X.

DECARY, S. et al. Shorter telomeres in dystrophic muscle consistent with extensive regeneration in young children. Neuromuscul Disord, v. 10, n. 2, p. 113-20, Feb 2000. ISSN 0960-8966.

DECARY, S. et al. Replicative potential and telomere length in human skeletal muscle: implications for satellite cell-mediated gene therapy. Hum Gene Ther, v. 8, n. 12, p. 1429-38, Aug 1997. ISSN 1043-0342.

DELAPORTE, C.; DEHAUPAS, M.; FARDEAU, M. Comparison between the growth pattern of cell cultures from normal and Duchenne dystrophy muscle. J Neurol Sci, v. 64, n. 2, p. 149-60, May 1984. ISSN 0022-510X.

DUMONT, N. A. et al. Dystrophin expression in muscle stem cells regulates their polarity and asymmetric division. Nat Med, v. 21, n. 12, p. 1455-63, Dec 2015. ISSN 1546-170X.

EHMSEN, J.; POON, E.; DAVIES, K. The dystrophin-associated protein complex. J Cell Sci, v. 115, n. Pt 14, p. 2801-3, Jul 2002. ISSN 0021-9533.

EMERY, A. E. The muscular dystrophies. BMJ, v. 317, n. 7164, p. 991-5, Oct 1998. ISSN 0959-8138.

EMERY, A. E. The muscular dystrophies. Lancet, v. 359, n. 9307, p. 687-95, Feb 2002. ISSN 0140-6736.

GIANAKOPOULOS, P. J. et al. MyoD directly up-regulates premyogenic mesoderm factors during induction of skeletal myogenesis in stem cells. J Biol Chem, v. 286, n. 4, p. 2517-25, Jan 2011. ISSN 1083-351X.

GREWAL, P. K.; HEWITT, J. E. Mutation of Large, which encodes a putative glycosyltransferase, in an animal model of muscular dystrophy. Biochim Biophys Acta, v. 1573, n. 3, p. 216-24, Dec 2002. ISSN 0006-3002.

HAWKE, T. J.; GARRY, D. J. Myogenic satellite cells: physiology to molecular biology. J Appl Physiol (1985), v. 91, n. 2, p. 534-51, Aug 2001. ISSN 8750-7587.

HESLOP, L.; MORGAN, J. E.; PARTRIDGE, T. A. Evidence for a myogenic stem cell that is exhausted in dystrophic muscle. J Cell Sci, v. 113 ( Pt 12), p. 2299-308, Jun 2000. ISSN 0021-9533. 
HOFFMAN, E. P.; BROWN, R. H.; KUNKEL, L. M. Dystrophin: the protein product of the Duchenne muscular dystrophy locus. Cell, v. 51, n. 6, p. 919-28, Dec 1987. ISSN 0092-8674.

ISHIMOTO, S. et al. A quantitative study of the muscle satellite cells in various neuromuscular disorders. J Neurol Sci, v. 62, n. 1-3, p. 303-14, Dec 1983. ISSN 0022$510 X$.

JASMIN, G. et al. Impaired muscle differentiation in explant cultures of Duchenne muscular dystrophy. Lab Invest, v. 50, n. 2, p. 197-207, Feb 1984. ISSN 0023-6837.

KIM, J. H. et al. Mechanisms of myoblast fusion during muscle development. Curr Opin Genet Dev, v. 32, p. 162-70, Jun 2015. ISSN 1879-0380.

KOTTLORS, M.; KIRSCHNER, J. Elevated satellite cell number in Duchenne muscular dystrophy. Cell Tissue Res, v. 340, n. 3, p. 541-8, Jun 2010. ISSN 1432-0878.

KUDRYASHOVA, E.; KRAMEROVA, I.; SPENCER, M. J. Satellite cell senescence underlies myopathy in a mouse model of limb-girdle muscular dystrophy $2 \mathrm{H}$. J Clin Invest, v. 122, n. 5, p. 1764-76, May 2012. ISSN 1558-8238.

LUND, T. C.; GRANGE, R. W.; LOWE, D. A. Telomere shortening in diaphragm and tibialis anterior muscles of aged mdx mice. Muscle Nerve, v. 36, n. 3, p. 387-90, Sep 2007. ISSN 0148-639X.

MARTINS, P. C. et al. Dmdmdx/Largemyd: a new mouse model of neuromuscular diseases useful for studying physiopathological mechanisms and testing therapies. Dis Model Mech, v. 6, n. 5, p. 1167-74, Sep 2013. ISSN 1754-8411.

MATECKI, S.; GUIBINGA, G. H.; PETROF, B. J. Regenerative capacity of the dystrophic (mdx) diaphragm after induced injury. Am J Physiol Regul Integr Comp Physiol, v. 287, n. 4, p. R961-8, Oct 2004. ISSN 0363-6119.

MAURO, A. Satellite cell of skeletal muscle fibers. J Biophys Biochem Cytol, v. 9, p. 493-5, Feb 1961. ISSN 0095-9901.

MERCURI, E.; MUNTONI, F. Muscular dystrophy: new challenges and review of the current clinical trials. Curr Opin Pediatr, v. 25, n. 6, p. 701-7, Dec 2013. ISSN 1531$698 X$.

MORGAN, J. E.; ZAMMIT, P. S. Direct effects of the pathogenic mutation on satellite cell function in muscular dystrophy. Exp Cell Res, v. 316, n. 18, p. 3100-8, Nov 2010. ISSN 1090-2422.

MUNTONI, F.; TORELLI, S.; BROCKINGTON, M. Muscular dystrophies due to glycosylation defects. Neurotherapeutics, v. 5, n. 4, p. 627-32, Oct 2008. ISSN 19337213.

PARKER, M. H.; SEALE, P.; RUDNICKI, M. A. Looking back to the embryo: defining transcriptional networks in adult myogenesis. Nat Rev Genet, v. 4, n. 7, p. 497-507, Jul 2003. ISSN 1471-0056. 
RAHIMOV, F.; KUNKEL, L. M. The cell biology of disease: cellular and molecular mechanisms underlying muscular dystrophy. J Cell Biol, v. 201, n. 4, p. 499-510, May 2013. ISSN 1540-8140.

ROSS, J. et al. Defects in glycosylation impair satellite stem cell function and niche composition in the muscles of the dystrophic Large(myd) mouse. Stem Cells, v. 30, n. 10, p. 2330-41, Oct 2012. ISSN 1549-4918.

RUDNICKI, M. A. et al. Inactivation of MyoD in mice leads to up-regulation of the myogenic HLH gene Myf-5 and results in apparently normal muscle development. Cell, v. 71, n. 3, p. 383-90, Oct 1992. ISSN 0092-8674.

RUDNICKI, M. A. et al. The molecular regulation of muscle stem cell function. Cold Spring Harb Symp Quant Biol, v. 73, p. 323-31, 2008. ISSN 1943-4456.

RUDNICKI, M. A. et al. MyoD or Myf-5 is required for the formation of skeletal muscle. Cell, v. 75, n. 7, p. 1351-9, Dec 1993. ISSN 0092-8674.

SEALE, P. et al. Pax7 is necessary and sufficient for the myogenic specification of CD45+:Sca1+ stem cells from injured muscle. PLoS Biol, v. 2, n. 5, p. E130, May 2004. ISSN 1545-7885.

SHADRACH, J. L.; WAGERS, A. J. Stem cells for skeletal muscle repair. Philos Trans R Soc Lond B Biol Sci, v. 366, n. 1575, p. 2297-306, Aug 2011. ISSN 14712970.

SHIN, J. et al. Wasting mechanisms in muscular dystrophy. Int J Biochem Cell Biol, v. 45, n. 10, p. 2266-79, Oct 2013. ISSN 1878-5875.

SICINSKI, P. et al. The molecular basis of muscular dystrophy in the mdx mouse: a point mutation. Science, v. 244, n. 4912, p. 1578-80, Jun 1989. ISSN 0036-8075.

SUNADA, Y.; CAMPBELL, K. P. Dystrophin-glycoprotein complex: molecular organization and critical roles in skeletal muscle. Curr Opin Neurol, v. 8, n. 5, p. 37984, Oct 1995. ISSN 1350-7540.

TIERNEY, M. T.; SACCO, A. Satellite Cell Heterogeneity in Skeletal Muscle Homeostasis. Trends Cell Biol, v. 26, n. 6, p. 434-44, Jun 2016. ISSN 1879-3088.

TOWNSEND, D. Finding the sweet spot: assembly and glycosylation of the dystrophinassociated glycoprotein complex. Anat Rec (Hoboken), v. 297, n. 9, p. 1694-705, Sep 2014. ISSN 1932-8494.

VAINZOF, M. et al. Animal models for genetic neuromuscular diseases. J Mol Neurosci, v. 34, n. 3, p. 241-8, Mar 2008. ISSN 0895-8696.

VAINZOF, M.; ZATZ, M. Protein defects in neuromuscular diseases. Braz J Med Biol Res, v. 36, n. 5, p. 543-55, May 2003. ISSN 0100-879X.

VAN ROOIJ, E.; OLSON, E. N. MicroRNAs: powerful new regulators of heart disease and provocative therapeutic targets. J Clin Invest, v. 117, n. 9, p. 2369-76, Sep 2007. ISSN 0021-9738. 
VENUTI, J. M. et al. Myogenin is required for late but not early aspects of myogenesis during mouse development. J Cell Biol, v. 128, n. 4, p. 563-76, Feb 1995. ISSN 00219525.

VICTOR DUBOWITZ, C. S. A. A. O. Muscle Biopsy: A Practical Approach. $4^{\mathrm{a}}$. England: Elsevier, 2013. 592.

WAKAYAMA, Y. et al. Quantitative ultrastructural study of muscle satellite cells in Duchenne dystrophy. Neurology, v. 29, n. 3, p. 401-7, Mar 1979. ISSN 0028-3878.

WALLACE, G. Q.; MCNALLY, E. M. Mechanisms of muscle degeneration, regeneration, and repair in the muscular dystrophies. Annu Rev Physiol, v. 71, p. 3757, 2009. ISSN 1545-1585.

WEBSTER, C.; BLAU, H. M. Accelerated age-related decline in replicative life-span of Duchenne muscular dystrophy myoblasts: implications for cell and gene therapy. Somat Cell Mol Genet, v. 16, n. 6, p. 557-65, Nov 1990. ISSN 0740-7750.

YOSHIDA, M.; OZAWA, E. Glycoprotein complex anchoring dystrophin to sarcolemma. J Biochem, v. 108, n. 5, p. 748-52, Nov 1990. ISSN 0021-924X.

ZAMMIT, P. S. Function of the myogenic regulatory factors Myf5, MyoD, Myogenin and MRF4 in skeletal muscle, satellite cells and regenerative myogenesis. Semin Cell Dev Biol, v. 72, p. 19-32, Dec 2017. ISSN 1096-3634. 